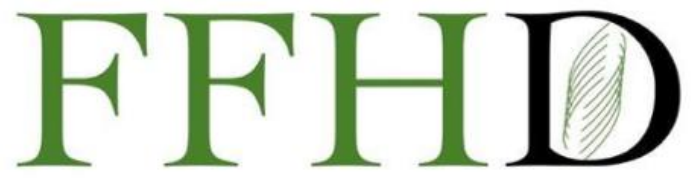

Functional Foods in Health and Disease

\title{
Functional foods' bioactive components and their chemoprevention mechanism in cervical, breast, and liver cancers: A systematic review
}

\author{
John Oluwafemi Teibo ${ }^{1}$, Kehinde Sulaimon Ayinde ${ }^{2}$, Olamide Tosin Olaoba ${ }^{3 *}$, Temitope Isaac \\ Adelusi $^{4}$, Titilade Kehinde Ayandeyi Teibo ${ }^{5}$, Makinde Victor Bamikunle ${ }^{4}$, Yomade Ayodeji Jimoh ${ }^{6}$, \\ Saad Alghamdi ${ }^{7}$, Osama Abdulaziz ${ }^{8}$, Abdur Rauf ${ }^{9}$, Gaber El-Saber Batiha ${ }^{10}$
}

\begin{abstract}
${ }^{1}$ Department of Biochemistry and Immunology, Ribeirão Preto Medical School, University of Sao Paulo, Ribeirão Preto, SPBrazil; ${ }^{2}$ Institute of Biology, State University of Campinas, Campinas-SP, Brazil; ${ }^{3}$ Department of Biochemistry, University of Missouri, Columbia, MO, United States; ${ }^{4}$ Department of Biochemistry, Ladoke Akintola University of Technology, Ogbomoso, Nigeria; ${ }^{5}$ Department of Maternal-Infant and Public Health Nursing, College of Nursing, Ribeirão Preto, University of São Paulo, Ribeirão Preto, SP-Brazil; ' Department of Biochemistry, Federal University of Technology, Akure, Nigeria; ${ }^{7}$ Laboratory Medicine Department, Faculty of Applied Medical Sciences, Umm Al-Qura University, Makkah, Saudi Arabia; ${ }^{8}$ Clinical Laboratory Sciences Department, College of Applied Medical Sciences, Taif University, Taif Province, Kingdom of Saudi Arabia; ${ }^{9}$ Department of Chemistry, University of Swabi, Swabi, Anbar-23561, K.P.K, Pakistan; ${ }^{10}$ Department of Pharmacology and Therapeutics, Faculty of Veterinary Medicine, Damanhour University, Damanhour 22511, Albeheira, Egypt.
\end{abstract}

*Corresponding Author: Olamide Tosin Olaoba, Department of Biochemistry, University of Missouri, Columbia, MO, United States.

Submission Date: June 18 ${ }^{\text {th }}$, 2021; Acceptance Date: October 18 ${ }^{\text {th }}, 2021$; Publication Date: November $5^{\text {th }}, 2021$

Please cite this as: Teibo J.O., Ayinde K.S., Olaoba O.T., Adelusi T.I., Teibo T.K.A., Bamikunle M.V., Jimoh Y.A., et al. Functional foods' bioactive components and their chemoprevention mechanism in cervical, breast, and liver cancers: A systematic review. Functional Foods in Health and Disease 2021; 11(11): 559-585. DOI: https://www.doi.org/10.31989/ffhd.v11i11.818

\section{ABSTRACT}

The invasiveness and low survivability on the part of patients associated with cancer continues to raise global concern. Different approaches have been used in the treatment and restoration of normalcy in cancer patients. However, most of the therapeutic strategies employed are challenged with high cost, low efficacy, high toxicity, and multiple side effects. In recent times, emergent studies have provided evidence that functional foods and their bioactive components serve roles as potential agents in the prevention and treatment of cancers. Moreover, global interest has focused on how this chemoprevention potential of functional foods can be explored as plant-based medicines for drug development. Although, the literature is replete with the mechanism of chemoprevention elicited by individual components of functional foods, there are limited reports on their overall anti-cancer mechanisms. 
Therefore, this systematic review aims to unify the anti-cancer mechanisms of functional foods in cervical, breast, and liver cancers which were selected due to their high incidence and mortality globally. We reviewed articles from NCBI/PUBMED from 2010 until February 2020. Three different search words used include "Functional food and cervical cancer"; "Functional foods and breast cancer"; "Functional foods and hepatocarcinoma". Consequently, 434 scientific papers resulted from the three search words. However, after applying the inclusion/exclusion criteria, 37 articles were selected: 14 on cervical cancer, 10 on breast cancer, and 13 on hepatocellular carcinoma. We subsequently emphasize the anti-cancer mechanisms of various functional foods in the studies selected and these include induction of apoptosis, cell cycle arrest, disruption of microtubular network, downregulation of anti-apoptotic Bcl-2 family expression, induction of autophagy, modulation of signaling cascades, ROS generation, and suppression of specific genes. Therefore, functional foods possess effective chemoprevention mechanisms which can be explored in drug development.

Keywords: Cervical cancer, Breast cancer, Liver cancer, Cancer prevention, Functional foods, Bioactive compounds

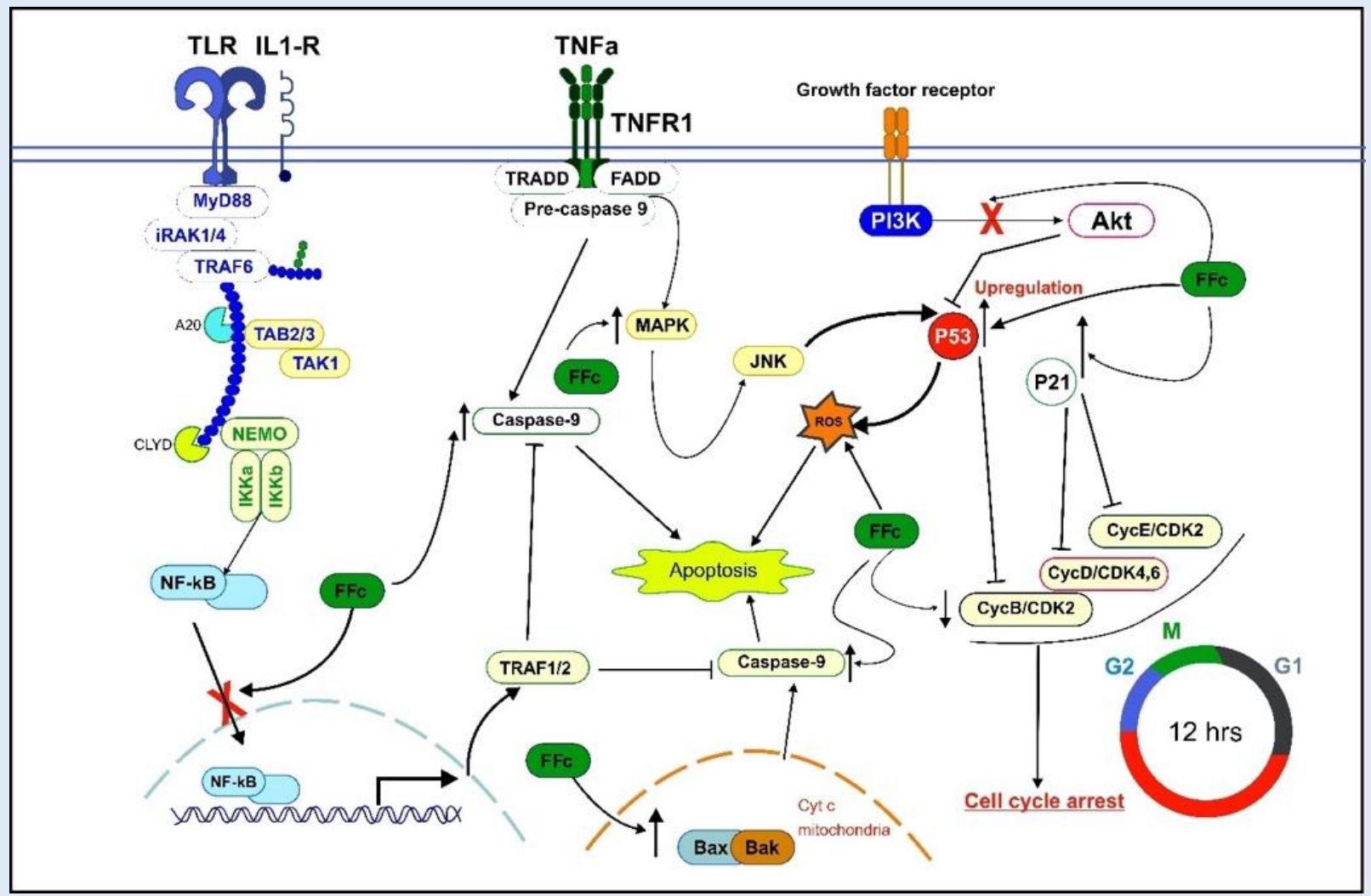

CFFC 2021. This is an Open Access article distributed under the terms of the Creative Commons Attribution 4.0 License (http://creativecommons.org/licenses/by/4.0)"

\subsection{INTRODUCTION}

The beneficial influence of bioactive food components has been the subject of many studies. [1-4]. Foods that contain bioactive ingredients are referred to as functional foods as they provide medical benefits other than their nutritional value [5]. They may provide the body with the appropriate quantity of biomolecules needed for its healthy upkeep [6]. Functional foods and conventional food can appear similar. However, differences between functional foods and conventional foods have been established. The physiological significance of functional foods has been demonstrated to include a reduction in 
risk and vulnerability to chronic diseases beyond the elementary nutritional significance and maintenance of gut health [6]. A document of the Functional Food Science in Europe (FUFOSE) elaborated the definition of Functional Foods to include those foods which "beneficially affect one or more target functions in the body beyond adequate nutritional effects in a way that is relevant to either an improved state of health and wellbeing and/or reduction of risk of disease" [7-8]. Such food with pro-health benefits [5] may be prophylactic $[2,5,7,9-$ 10].

In the mid-1980s, the term "Functional Foods" was first introduced in Japan and has been described as processed foods, which in addition to being nutritious consists of ingredients that enhance specific bodily functions. The Foods for Specified Health Use (FOSHU) is a specific regulatory approval process for functional foods in Japan, with such foods bearing a seal of approval from the Japanese Ministry of Health and Welfare [11]. Meyer reported that Functional Foods made by healthconscious baby boomers are the leading trend in the United State food industry [12], with a market value at $\$ 28.9$ billion [13]. More important is the potential of Functional Foods to mollify diseases, improve health, and minimize health care costs [13].

Functional foods can contain various proportions of nutrients (such as vitamins, minerals, fibers, electrolytes among others) alongside numerous naturally occurring bioactive substances in plant foods called phytochemicals. Such foods of plant origin possess antioxidant activity, which is one of the numerous anticancer properties. Other health-promoting properties of plants include anti-proliferative, anti-inflammatory, antipyretic, analgesic, anti-viral, anti-bacterial, and neuroprotective activities [14]. These plants include fruits, vegetables, beans, legumes, nuts, whole grains, herbs, and spices [15]. Phytochemicals (some are also known as phytonutrients) are naturally occurring substances produced in certain metabolic pathway in plants. Some have been shown to be responsible for the putative health benefits of plant-based foods. Phytochemicals have been classified based on their structure and properties such as flavonoids, flavonols, flavanols, proanthocyanidins, and procyanidins [16] and also include carotenoid, other phenolic compounds, phytosterols and phytostanols, tocotrienols, organosulfur compounds, non-digestible carbohydrates, saponins, salicylates, glucosinolates, protease inhibitors, monoterpenes, phytoestrogens, terpenes, lectins and many more [17].

Cancer is a multifactorial disease, which remains a global concern and has been adjudged to be idiopathic in several cases though could be triggered by several factors which include radiation, chemical, and viruses among others [18]. Cancer has a long history, recorded as far back as $3000 \mathrm{BC}$, and has so much sporadically increased to have claimed millions of lives worldwide. In 2020, approximately 19.3 million new cases and 10 million mortalities were announced. 1 of every 5 men and 1 of every 6 women globally developed cancer in their lifetime, and 1 out of 8 men and 1 out of 11 women died as a result of cancer. Globally, the total sum of people who are alive during 5 years of their cancer diagnosis, named the 5-year prevalence, is approximately 20.6 million. The burden of cancer increases as a result of population growth, aging, and direct link between some types of cancer and socio-economic development [19]. The International Agency for Research on Cancer (IARC) has estimated the cancer incidence rate based on gender to be one-in-five men and one-in-six women globally. 
These subjects have the tendency to develop cancer over the course of their lifetime, and the mortality rate is one in eight men and one in eleven women [20]. Several factors appear to be the driving force for this observed increase, most especially a growing and aging global population and an exponential increase in exposure to cancer risk factors and carcinogenic substances [20]. The continent of Asia accounts for nearly half of the reported new cancer cases globally and more than half of cancerrelated deaths. Asia and Africa have a higher proportion of death due to cancer ( $7.3 \%$ and $57.3 \%$ respectively) compared with their incidence rate $(5.8 \%$ and $48.4 \%$ respectively). IARC suggests this trend is likely due to the higher frequency of cancer types associated with poorer prognosis, along with limited access to timely diagnosis and treatment [18].

Cervical cancer, otherwise called cancer of the cervix, is associated with the lower and narrower end of the uterus. The cervical canal connects the uterus and the vagina of the female reproductive system. However, cervical cancer and breast cancer ranks as the most common female malignancies when both incidence and mortality rates are being considered on a global scale. More than 200,000 cancer-related deaths are reported due to cervical cancer each year, predominantly among economically disadvantaged women in both developing and industrialized nations. The world's highest rates of cervical cancer incidence and death are from subSaharan Africa, including South Africa with a rate of $40 / 100,000$. Cervical cancer is a public health challenge as it is the commonest female genital tract cancer worldwide.

Breast cancer is the most frequently occurring cancer and the leading cause of death in women between the ages of 20 and 59 years in the United States [21]. It is estimated that about one in eight US women will develop invasive breast cancer over the course of her lifetime. In 2018 , over 266,000 new cases of invasive breast cancer were expected to be diagnosed in women in the U.S., along with nearly 64,000 new cases of noninvasive breast cancer in US women [22-23]. As of January 2018, there are already more than 3.1 million US women with a history of breast cancer, which includes the women currently being treated as well as women who have undergone a treatment plan. Furthermore, it is the second most common cancer in terms of both incidence and mortality in African women. Notably, breast cancer has a complex etiology where susceptibility is influenced by both environmental and genetic factors. Considerable experimental and epidemiological evidence suggests that lifetime exposure to endogenous hormones, such as estrogens and androgens, promotes breast carcinogenesis. The extensive molecular and pathological diversities observed in breast cancer patients suggests that breast cancer is not a homogeneous disease that can be effectively managed by a "standard of care" approach [24]. Liver cancer is often fatal and occurs worldwide. The liver is an essential organ that plays major and vital roles in the metabolic economy of the body. As a result of its central role in survival and existence, it is exposed to a barrage of antigens and xenobiotics, some of which are infectious and sometimes carcinogenic. Liver cancer is majorly divided into two categories, those being, primary liver cancer and secondary or metastatic liver cancer. In countries with low prevalence of Hepatitis B virus (HBV) infection, liver metastases are the major cause of liver cancer death induced by secondary liver cancer, while in regions with high prevalence of HBV such as China and sub-Sahara Africa, Hepatocellular carcinoma (HCC) accounts for most of the liver cancer cases. It is however common in regions of the world where risk factors are more prevalent. Worldwide, HCC is the sixth most 
common cancer, the fifth most common cancer in men, and the eighth-most common in women. Most of the over 600,000 annual deaths attributable to HCC occur in Asia and sub-Sahara Africa, mainly because of the endemicity of the major risk factors [25].

The emerging role of functional foods in the prevention, treatment, and management of various cancers viz a viz cervical, breast, and liver cancer is increasing and within which lies an area of global interest in research for novel functional foods. Therefore, elucidation of their molecular mechanisms and interactions may fulfill an overall goal of how they exert their anticancer, anti-proliferative and anti-tumor effects in various cancers.

\subsection{METHODS}

The authors reviewed articles from NCBI/PUBMED until February 2020 while taking into account certain inclusion and exclusion factors. Since three different types of cancer were considered, thus, three different search words were used to collect data from the database: "Functional food and cervical cancer", "Functional foods
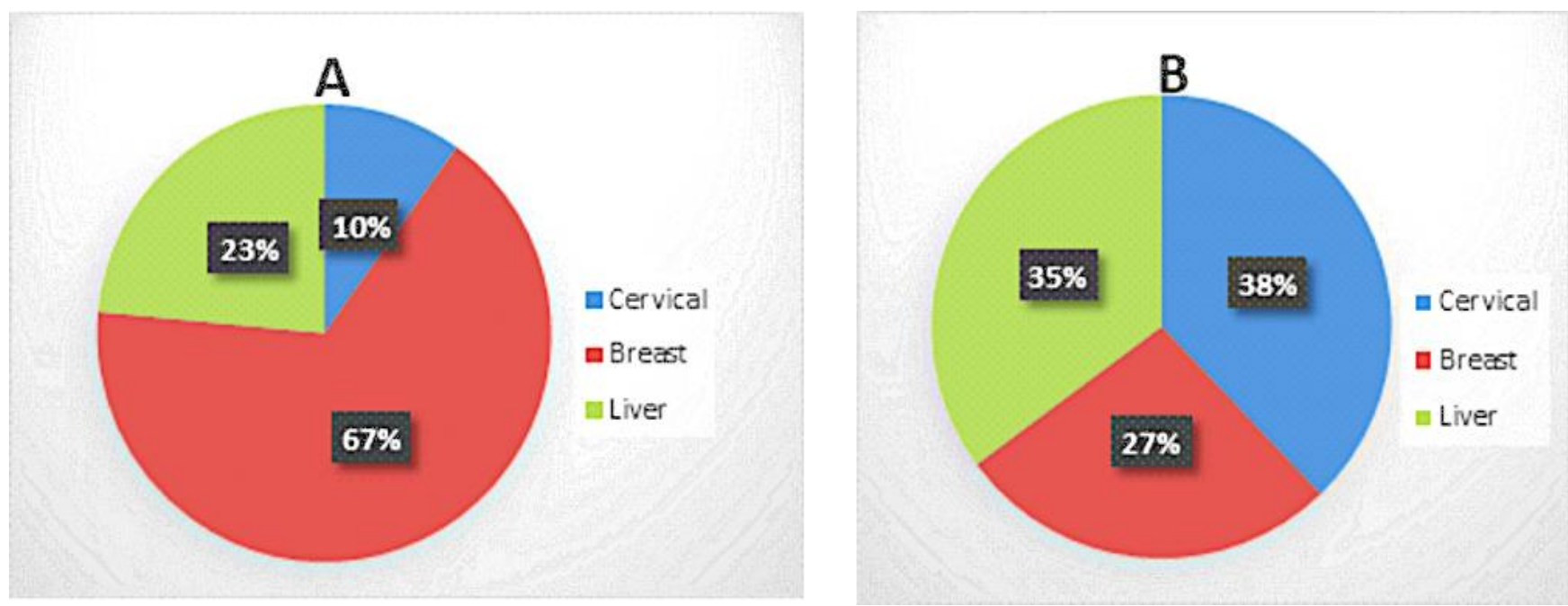

Figure 1. The distribution in percentage of articles obtained from pool of search and the percentage of articles finally selected for the review. and breast cancer", and "Functional foods and hepatocarcinoma". The inclusion factors considered by the authors are, (1) publications within the last 10 years on cervical cancer, and 5 years for breast and liver cancers, (2) original research articles, (3) both in vivo and in vitro studies were considered, and (4) works related to the author's consideration. However, review articles, unrelated works, and synthetic functional food were excluded.

\subsection{RESULTS}

There were 434 scientific papers resulting from the search on PubMed - 43 search results are related to cervical cancers, 289 are related to breast cancer, and 102 are related to hepatocellular carcinoma. However, after applying the inclusion and exclusion factors, 37 articles were selected in total - 14 articles on cervical cancer, 10 articles on breast cancer, and 13 articles on hepatocellular carcinoma. Figure 1 and tables 1, 2, and 3 below summarize the articles selected. 
Table 1. Summary of articles in this review: cervical cancer

\begin{tabular}{|c|c|c|c|c|c|}
\hline Author & Title & $\begin{array}{l}\text { Functional Food } \\
\text { Component }\end{array}$ & Methods & Results & Conclusion \\
\hline$[25]$ & $\begin{array}{l}\text { Arabinogalactan derived } \\
\text { from Lycium barbarum } \\
\text { fruit inhibits cancer cell } \\
\text { growth via cell cycle } \\
\text { arrest and apoptosis }\end{array}$ & $\begin{array}{l}\text { Arabinogalactan } \\
\text { (LBGP-I-3) }\end{array}$ & $\begin{array}{l}\text { Purification of } L \text {. barbarum } \\
\text { fruit by alcohol fractional } \\
\text { precipitation and evaluation } \\
\text { of its effect on cancer cells }\end{array}$ & $\begin{array}{l}\text { Impaired growth of } \\
\text { MCF-7 cells, SMMC- } \\
7721 \text { and HeLa- } \\
\text { cervical cancer cell } \\
\text { (cell viability of } \\
55.94 \% \text { ) }\end{array}$ & $\begin{array}{l}\text { LBGP-I-3 may be a } \\
\text { potential anticancer } \\
\text { functional food for the } \\
\text { prevention (prophylaxis) of } \\
\text { cancer. }\end{array}$ \\
\hline [26] & $\begin{array}{l}\text { Methyl protodioscin from } \\
\text { Polygonatum sibiricum } \\
\text { inhibits cervical cancer } \\
\text { through cell cycle arrest } \\
\text { and apoptosis induction }\end{array}$ & Methyl protodioscin & $\begin{array}{l}\text { Methyl protodioscin was } \\
\text { purified from } P \text {. sibricum } \\
\text { and applied to the cervical } \\
\text { HeLa cell lines, for analysis } \\
\text { ex post facto. }\end{array}$ & $\begin{array}{l}\text { Inhibition of Hela cell } \\
\text { proliferation in a } \\
\text { dose-dependent } \\
\text { manner via changes } \\
\text { in HeLa cell } \\
\text { morphology, cell cycle } \\
\text { repression, apoptosis } \\
\text { and ROS generation }\end{array}$ & $\begin{array}{l}\text { MPD can be incorporated } \\
\text { as natural anti-cancer drug } \\
\text { in therapeutic strategies. }\end{array}$ \\
\hline [27] & $\begin{array}{l}\text { Apoptotic effect of a } \\
\text { phytosterol-ingredient } \\
\text { and its main phytosterol } \\
\text { ( } \beta \text {-sitosterol) in human } \\
\text { cancer cell lines }\end{array}$ & $\begin{array}{l}\text { Phytosterol (PS)- } \\
\text { ingredient } \\
\text { ( } \beta \text {-sitosterol) }\end{array}$ & $\begin{array}{l}\text { Human breast (MCF-7), } \\
\text { colon (HCT116) and cervical } \\
\text { cancer (HeLa) cells were } \\
\text { cultured, seeded and } \\
\text { treated with tall oil PS- } \\
\text { ingredient or } \beta \text {-sitosterol at } \\
\text { different concentration } \\
\text { with subsequent viability } \\
\text { assay, cell cycle analysis and } \\
\text { assessment of apoptosis }\end{array}$ & $\begin{array}{l}\text { Overall reduction in } \\
\text { cell viability. Absence } \\
\text { of dose-response } \\
\text { effect of PS on MCF-7 } \\
\text { and HCT116 cells. } \\
\text { However, there was a } \\
\text { dose-response effect } \\
\text { on HeLa cell. }\end{array}$ & $\begin{array}{l}\text { As much as further } \\
\text { research is encouraged, } \\
\text { current data surmised that, } \\
\text { PS-ingredient may be } \\
\text { referred to as } \\
\text { anticarcinogenic substance } \\
\text { against colon, breast and } \\
\text { cervical cancers. }\end{array}$ \\
\hline [28] & $\begin{array}{l}\text { Biotin-Modified } \\
\text { Polylactic-co-Glycolic } \\
\text { Acid Nanoparticles with } \\
\text { Improved } \\
\text { Antiproliferative Activity } \\
\text { of } 15,16- \\
\text { Dihydrotanshinone I in } \\
\text { Human Cervical Cancer } \\
\text { Cells }\end{array}$ & $\begin{array}{l}15,16- \\
\text { Dihydrotanshinone I } \\
\text { (DI) }\end{array}$ & $\begin{array}{l}\text { Encapsulation of DI into DI- } \\
\text { PPA-NPs and DI-BPA-NPs } \\
\text { copolymers and the } \\
\text { evaluation of its } \\
\text { antiproliferative activity on } \\
\text { the human cervical HeLa } \\
\text { cells. }\end{array}$ & $\begin{array}{l}\text { Free DI and the } \\
\text { copolymers impaired } \\
\text { growth of HeLa cells } \\
\text { in dose and time } \\
\text { dependent fashion. }\end{array}$ & $\begin{array}{l}\text { There is enhancement of } \\
\text { the growth impairment } \\
\text { ability of DI when } \\
\text { incorporated into } \\
\text { copolymer thereby further } \\
\text { showing its potential use as } \\
\text { cancer therapy. }\end{array}$ \\
\hline [29] & $\begin{array}{l}\text { LC-ESI-TOF-MS and GC- } \\
\text { MS profiling of Artemisia } \\
\text { herba-alba and } \\
\text { evaluation of its bioactive } \\
\text { properties }\end{array}$ & $\begin{array}{l}\text { di-O-caffeoylquinic } \\
\text { acids, artemisinic acid, } \\
\text { menthol, } \alpha- \\
\text { ketoglutaric acid, } \\
\text { scopolin, } \\
\text { isoschaftoside and } \\
\text { sucrose. }\end{array}$ & $\begin{array}{l}\text { Component identification } \\
\text { using LC-ESI-TOF-MS and } \\
\text { GC-EI-MS. Cell - MCF-7 } \\
\text { breast cancer and HeLa } \\
\text { human cervical cell lines - } \\
\text { viability assay. }\end{array}$ & $\begin{array}{l}\text { Dose-dependent } \\
\text { inhibition of cellular } \\
\text { proliferation of HeLa } \\
(15 \mu \mathrm{g} / \mathrm{ml}) \text { and MCF-7 } \\
(70 \mu \mathrm{g} / \mathrm{ml}) \text { cell }\end{array}$ & $\begin{array}{l}\text { Herba alba can be } \\
\text { alternatively used as } \\
\text { bioactive component in } \\
\text { functional foods, } \\
\text { nutraceuticals and dietary } \\
\text { supplement. }\end{array}$ \\
\hline [30] & $\begin{array}{l}\text { Molecular mechanism of } \\
\text { anti-cancerous potential } \\
\text { of Morin extracted from } \\
\text { mulberry in Hela cells }\end{array}$ & Morin & $\begin{array}{l}\text { Morin extraction and } \\
\text { purification with HPLC } \\
\text { followed by treatment on } \\
\text { HeLa cell. Cell viability (MTT } \\
\text { assay), Flow cytometry for } \\
\text { cell cycle and apoptosis } \\
\text { analysis etc. }\end{array}$ & $\begin{array}{l}\text { Inhibition of HeLa cell } \\
\text { proliferation, } \\
\text { morphological } \\
\text { changes, cancer cell } \\
\text { cycle arrest and } \\
\text { induction of apoptosis } \\
\text { in dose-dependent } \\
\text { fashion }\end{array}$ & $\begin{array}{l}\text { New treatment strategy in } \\
\text { the future will involve the } \\
\text { synergy of morin and other } \\
\text { anti-cancer molecule, and } \\
\text { as functional food, it can } \\
\text { elicit its anti-neoplastic } \\
\text { effects. }\end{array}$ \\
\hline [31] & $\begin{array}{l}\text { Dietary flavonoids, } \\
\text { luteolin and quercetin, } \\
\text { inhibit invasion of cervical } \\
\text { cancer by reduction of } \\
\text { UBE2S through epithelial- } \\
\text { mesenchymal transition } \\
\text { signaling }\end{array}$ & Luteolin and quercetin & $\begin{array}{l}\text { Culturing of human cervical } \\
\text { epithelial cancer cell A431- } \\
\text { III cells. Cell viability assay- } \\
\text { seeded cells were incubated } \\
\text { with luteolin and quercetin } \\
\text { at varying concentration } \\
\text { overnight. }\end{array}$ & $\begin{array}{l}\text { Inhibition of tumour } \\
\text { invasion via the } \\
\text { inhibition of ubiquitin } \\
\text { E2S ligase expression } \\
\text { (this expression was } \\
\text { paralleled to the } \\
\text { metastatic and } \\
\text { invasive capacity of } \\
\text { cervical cancer cells }\end{array}$ & $\begin{array}{l}\text { Dietary luteolin and } \\
\text { quercetin possesses } \\
\text { autonomous ability to } \\
\text { disrupt malignancy via the } \\
\text { alteration of UBE2S } \\
\text { expression }\end{array}$ \\
\hline
\end{tabular}




\begin{tabular}{|c|c|c|c|c|c|}
\hline Author & Title & $\begin{array}{l}\text { Functional Food } \\
\text { Component }\end{array}$ & Methods & Results & Conclusion \\
\hline [32] & $\begin{array}{l}\text { Hazelnut (Corylus } \\
\text { avellana L.) Shells Extract: } \\
\text { Phenolic Composition, } \\
\text { Antioxidant Effect and } \\
\text { Cytotoxic Activity on } \\
\text { Human Cancer Cell Lines }\end{array}$ & $\begin{array}{l}\text { Neolignans, cedrusin, } \\
\text { balanophonin, gallic } \\
\text { acid etc. }\end{array}$ & $\begin{array}{l}\text { Methanol extraction of } \\
\text { different } \\
\text { composition. } \\
\text { scavenging ability and MTT } \\
\text { cell viability assay for A375 } \\
\text { (melanoma) and HeLa } \\
\text { (cervical) cells }\end{array}$ & $\begin{array}{l}\text { Proapoptotic effect } \\
\text { and induction of } \\
\text { apoptosis in A375 and } \\
\text { HeLa cells through the } \\
\text { cleavage of PARP-1 } \\
\text { and caspase-3 } \\
\text { activation }\end{array}$ & $\begin{array}{l}\text { Hazelnut shell's extract } \\
\text { might be useful as } \\
\text { functional } \\
\text { component, food } \\
\text { supplement and or } \\
\text { ingredient of nutraceuticals }\end{array}$ \\
\hline
\end{tabular}

[33] Antioxidant and antiproliferative activities in immature and mature wheat kernels

[34]

A detailed comparative study between chemical and bioactive properties of Ganoderma lucidum from different origins

Growth-Inhibitory Effects of Pigmented Rice Bran Extracts and Three Red Bran Fractions against Human Cancer Cells: Relationships with Composition and Antioxidative Activities

Lycium barbarum polysaccharide inhibits the proliferation of HeLa cells by inducing apoptosis

Aqueous extract of ginger shows antiproliferative activity through disruption of microtubule network of cancer cells

Induction of apoptosis in
Phenolics and

flavonoids
Ethanolic extraction of Higher concentration assay to determine the antiproliferative effect in human colon cancer (HT-29) and human cervical (HeLa) cell

Reducing sugars, organic acids, phenolic compounds, unsaturated fatty acids, tocopherols and ergosterol

Phenolics, anthocyanin, and proanthocyanidin human cervical carcinoma HeLa cells by polymethoxylated flavone-rich Citrus grandis Osbeck (Dangyuja) leaf extract phenolic content and MTT

of total phenolic content in immature wheat contributed inhibition of about $50 \%$ cell proliferation in HT-29 and HeLa cells than in mature wheat.

Ganoderma lucidum from Serbia showed growth inhibition upon its treatment on the five human cancer cell lines

MTT assay and determination of $\mathrm{IC}_{50}$

Red bran inhibited proliferation in leukemia, cervical and stomach cell lines.
Lycium barbarum polysaccharide (LBP)

Preparation of LBP; MTT assay for cell viability; cell cycle analysis via flow cytometry and measurement of nitrite/nitrate concentration in HeLa cell medium

Flavones and flavonols

Preparation of aqueous extract (GAE), culturing of HeLa cell, MTT cell viability assay, DNA synthesis analysis, cell cycle analysis and apoptosis analysis

Methanolic extract of $C$. grandis Osbeck, culturing of tumour cell lines, cell viability assay and analysis of morphological changes HeLa cell and other human
Inhibition of Hela cell proliferation through dose dependent $\mathrm{S}$ phase cell cycle arrest, induction of apoptosis and NOinduced cell death.

Loss of cell viability in HeLa cell, increased population of subG $G_{0} / G_{1}$ phase and induction of apoptosis

Leaf extracts diminished cell viability in a dose dependent fashion. Fraction also induce changes in cell morphology including; chromatin fragmentation and cell death
Immature wheat extract inhibited cell proliferation more strongly than mature wheat.

The methanolic extract gave a promising antiproliferative effect without hepatotoxicity

Red bran can be used as functional food for human consumption
LBP may be a potentia drug for the control of cancer

GAE components can be further screened and used for the development of anti-cancer agent

Dangyuja leaves contain functional component of poly methoxylated flavones which can prevent cervical cancer. 
Table 2. Summary of articles in this review: Breast Cancer

\begin{tabular}{|c|c|c|c|c|c|}
\hline Author & Title & $\begin{array}{l}\text { Functional Food } \\
\text { Component }\end{array}$ & Methods & Results & Conclusion \\
\hline [39] & $\begin{array}{l}\text { DT-13 inhibits breast } \\
\text { cancer cell migration } \\
\text { via non-muscle } \\
\text { myosin II-A regulation } \\
\text { in tumor } \\
\text { microenvironment } \\
\text { synchronized } \\
\text { adaptations }\end{array}$ & $\begin{array}{l}\text { Dwarf-lillytruf } \\
\text { Tuber monomer- } \\
13 \text { (DT-13) }\end{array}$ & $\begin{array}{l}\text { Co-culturing system } \\
\text { where tumor cells } \\
\text { are co-cultured with } \\
\text { hypoxia induced } \\
\text { cancer-associated } \\
\text { fibroblast or } \\
\text { chemically induced } \\
\text { cancer-associated } \\
\text { adipocytes; cell } \\
\text { migration analysis, } \\
\text { western blot probe } \\
\text { for expression } \\
\text { analysis }\end{array}$ & $\begin{array}{l}\text { Breast cell } \\
\text { migration via } \\
\text { stroma cells was } \\
\text { directly influenced } \\
\text { by Tumour } \\
\text { Microenvironment } \\
\text { (TME), however, } \\
\text { TME dependent cell } \\
\text { migration was } \\
\text { inhibited by DT-13 } \\
\text { by targeting NMII-A } \\
\text { (Non-muscle myosin } \\
\text { II-A) }\end{array}$ & $\begin{array}{l}\text { TME is a prospective } \\
\text { therapeutic target for } \\
\text { the modulation of the } \\
\text { loss of anchorage } \\
\text { dependent growth in } \\
\text { breast cancer. }\end{array}$ \\
\hline [40] & $\begin{array}{l}\text { The dietary c } 9, \mathrm{t} 11- \\
\text { conjugated linoleic } \\
\text { acid enriched from } \\
\text { butter reduces breast } \\
\text { cancer progression in } \\
\text { vivo. }\end{array}$ & $\begin{array}{l}\text { c9,t11-conjugated } \\
\text { linoleic acid }\end{array}$ & $\begin{array}{l}\text { Urea complexation } \\
\text { of FFA to obtain c8, } \\
\text { t11-CLA, animal } \\
\text { study, } \\
\text { histopathological } \\
\text { and } \\
\text { immunochemistry }\end{array}$ & $\begin{array}{l}\text { c9,t11-CLA } \\
\text { decreased the } \\
\text { tumor weight and } \\
\text { volume, and } \\
\text { reduced the tumor } \\
\text { incidence up to } 50 \% \\
\text { in the tumor } \\
\text { induced rats. }\end{array}$ & $\begin{array}{l}\text { The study confirms the } \\
\text { preventive activity of } \\
\text { c9,t11-CLA against } \\
\text { breast cancer in animal } \\
\text { models. }\end{array}$ \\
\hline [25] & $\begin{array}{l}\text { Arabinogalactan } \\
\text { derived from Lycium } \\
\text { barbarum fruit } \\
\text { inhibits cancer cell } \\
\text { growth via cell cycle } \\
\text { arrest and apoptosis }\end{array}$ & $\begin{array}{l}\text { Arabinogalactan } \\
\text { (LBGP-I-3) }\end{array}$ & $\begin{array}{l}L \text { barbarum fruit } \\
\text { crude } \\
\text { polysaccharide } \\
\text { extraction and } \\
\text { purification. Cell } \\
\text { viability and colony } \\
\text { formation assay. }\end{array}$ & $\begin{array}{l}\text { The LBGP-I-3 } \\
\text { showed strong } \\
\text { inhibitory effect on } \\
\text { MCF-7 cell } \\
\text { proliferation by } \\
\text { downregulating } \\
\text { BCL-2/Bax } \\
\text { expression and } \\
\text { upregulating } \\
\text { caspase-3, } 8 \text { and } 9 \\
\text { among others. }\end{array}$ & $\begin{array}{l}\text { LBGP-I-3 may be a } \\
\text { potential anticancer } \\
\text { functional food for the } \\
\text { prevention } \\
\text { (prophylaxis) of } \\
\text { cancer. }\end{array}$ \\
\hline [41] & $\begin{array}{l}\text { Genistein Inhibits } \\
\text { Proliferation } \\
\text { of } B R C A 1 \text { Mutated } \\
\text { Breast Cancer Cells: } \\
\text { The GPR30-Akt Axis as } \\
\text { a Potential Target. }\end{array}$ & Genistein & $\begin{array}{l}\text { Expression of } \\
\text { BRCA1, GPR30 and } \\
\text { Nrf2. Effects of } \\
\text { genistein on breast } \\
\text { cancer cell viability } \\
\text { and proliferation } \\
\text { were assessed by } \\
\text { the MTT, migration } \\
\text { and clonogenic } \\
\text { assays. }\end{array}$ & $\begin{array}{l}\text { BRCA1 silenced } \\
\text { breast cancer cells } \\
\text { treated with } \\
\text { genistein resulted in } \\
\text { the down- } \\
\text { regulation of GPR30 } \\
\text { expression causing } \\
\text { reduction in cell } \\
\text { viability, migration } \\
\text { and colony } \\
\text { formation. }\end{array}$ & $\begin{array}{l}\text { Genistein is a } \\
\text { chemopreventive } \\
\text { isoflavone capable of } \\
\text { suppressing cancer cell } \\
\text { growth in BRCA } 1 \\
\text { impaired breast cancer } \\
\text { cells. }\end{array}$ \\
\hline [42] & $\begin{array}{l}\text { Vicilin - A major } \\
\text { storage protein of } \\
\text { mungbean exhibit } \\
\text { antioxidative } \\
\text { potential, anti- } \\
\text { proliferative effect } \\
\text { and ACE inhibitory } \\
\text { activity. }\end{array}$ & $\begin{array}{l}\text { Mungbean Vicilin } \\
\text { Protein (MBVP) }\end{array}$ & $\begin{array}{l}\text { Extraction and } \\
\text { purification and } \\
\text { antioxidant assay of } \\
\text { mungbean protein. } \\
\text { MTT cell viability } \\
\text { assay against breast } \\
\text { cancer cell lines } \\
\text { MCF-7 and MDA- } \\
\text { MB-231. }\end{array}$ & $\begin{array}{l}\text { MBVP showed } \\
\text { significant anti- } \\
\text { proliferative activity } \\
\text { and strong } \\
\text { antioxidant } \\
\text { capacity. }\end{array}$ & $\begin{array}{l}\text { MBVP may serve as a } \\
\text { physiologically active } \\
\text { functional food in the } \\
\text { treatment of breast } \\
\text { cancer. }\end{array}$ \\
\hline
\end{tabular}




\begin{tabular}{|c|c|c|c|c|c|}
\hline Author & Title & $\begin{array}{l}\text { Functional Food } \\
\text { Component }\end{array}$ & Methods & Results & Conclusion \\
\hline [43] & $\begin{array}{l}\text { The impact of Soy } \\
\text { Isoflavones on MCF-7 } \\
\text { and MDA-MB-231 } \\
\text { breast cancer cells } \\
\text { using global } \\
\text { metabolomics } \\
\text { approach }\end{array}$ & Soy Isoflavones & $\begin{array}{l}\text { Treatment of soy } \\
\text { extract with breast } \\
\text { cancer cells and MTT } \\
\text { assay. Proton NMR } \\
\text { and GS-MS analysis. }\end{array}$ & $\begin{array}{l}\text { Isoflavone elicited } \\
\text { dose-dependent } \\
\text { proliferative and } \\
\text { cell death initiation } \\
\text { activity. Modulation } \\
\text { of glucose uptake } \\
\text { suggested by } \\
\text { metabolomics. }\end{array}$ & $\begin{array}{l}\text { Metabolomics can be } \\
\text { of immense help in } \\
\text { understanding chemo- } \\
\text { preventive } \\
\text { mechanisms of soy } \\
\text { isoflavones, a potent } \\
\text { functional food in } \\
\text { breast cancer } \\
\text { prevention }\end{array}$ \\
\hline [44] & $\begin{array}{l}\text { Antineoplastic effects } \\
\text { of clove buds } \\
\text { (Syzygium } \\
\text { aromaticum L.) in the } \\
\text { model } \\
\text { of breast carcinoma }\end{array}$ & $\begin{array}{l}\text { Phenolic acid, } \\
\text { flavonol } \\
\text { glucoside, tannins } \\
\text { and phenolic } \\
\text { volatile oils }\end{array}$ & $\begin{array}{l}\text { MTS colorimetric } \\
\text { assay was used to } \\
\text { determine cytotoxic } \\
\text { effects of extracts on } \\
\text { MCF-7 cell lines. GC- } \\
\text { MS and LC-MS } \\
\text { analysis of extract. }\end{array}$ & $\begin{array}{l}\text { In vitro studies } \\
\text { showed pro- } \\
\text { apoptotic and } \\
\text { antiproliferative } \\
\text { effects of extract in } \\
\text { MCF-7 cells. }\end{array}$ & $\begin{array}{l}\text { Regular consumption } \\
\text { of Clove buds may be } \\
\text { beneficial for the risk } \\
\text { reduction of breast } \\
\text { cancer. }\end{array}$ \\
\hline [45] & $\begin{array}{l}\text { Pitaya pitaya } \\
\text { (Hylocereus } \\
\text { polyrhizus) } \\
\text { extract induces } \\
\text { growth inhibition and } \\
\text { pro-apoptotic effect } \\
\text { on human cell lines of } \\
\text { breast cancer via } \\
\text { downregulation of } \\
\text { estrogen receptor } \\
\text { gene expression. }\end{array}$ & Anthocyanin & $\begin{array}{l}\text { Extraction and } \\
\text { quantification of } \\
\text { antioxidant } \\
\text { activities, } \\
\text { determination of cell } \\
\text { viability against } \\
\text { MCF-7 and MDA- } \\
\text { MB-435 }\end{array}$ & $\begin{array}{l}\text { Extract showed } \\
\text { antitumor effect on } \\
\text { breast cancer cell } \\
\text { line by inducing } \\
\text { apoptosis and } \\
\text { suppressing BRCA1, } \\
\text { BRCA2, PRAB gene } \\
\text { expression }\end{array}$ & $\begin{array}{l}\text { Pitaya may have } \\
\text { strong therapeutic } \\
\text { potential in the } \\
\text { treatment and } \\
\text { prevention of breast } \\
\text { cancer. }\end{array}$ \\
\hline [46] & $\begin{array}{l}\text { Herbal remedies and } \\
\text { functional foods used } \\
\text { by cancer patients } \\
\text { attending specialty } \\
\text { oncology clinics in } \\
\text { Trinidad }\end{array}$ & & $\begin{array}{l}\text { Cross sectional } \\
\text { survey at two } \\
\text { specialty treatment } \\
\text { centers. }\end{array}$ & $\begin{array}{l}\text { Soursop (Annona } \\
\text { muricata L.) was the } \\
\text { most popular; with } \\
80.7 \% \text { usage among } \\
150 \text { patients. } \\
\text { Leaves, bark, fruit } \\
\text { and seed were } \\
\text { reported to be used } \\
\text { on a regular basis. }\end{array}$ & $\begin{array}{l}\text { The survey unearthed } \\
\text { the most common } \\
\text { herbal remedies and } \\
\text { functional foods used } \\
\text { among cancer } \\
\text { patients. Despite the } \\
\text { lack of evidence, } \\
\text { patients still believe in } \\
\text { the efficacy of these } \\
\text { alternative remedies. }\end{array}$ \\
\hline [47] & $\begin{array}{l}\text { Petroselinum crispum } \\
\text { has antioxidant } \\
\text { properties, protects } \\
\text { against DNA damage } \\
\text { and inhibits } \\
\text { proliferation and } \\
\text { migration } \\
\text { of cancer cells. }\end{array}$ & & $\begin{array}{l}\text { Two human breast } \\
\text { adenocarcinoma cell } \\
\text { lines - MCF-7 and } \\
\text { MDA-MB-231. The } \\
\text { extract was tested } \\
\text { for its } \\
\text { antiproliferative } \\
\text { potential against the } \\
\text { cell line using MTT } \\
\text { assay. Also, comet } \\
\text { assay was used to } \\
\text { test its DNA- } \\
\text { protective effect. }\end{array}$ & $\begin{array}{l}\text { The } \\
\text { dichloromethane } \\
\text { extract was more } \\
\text { potent } \\
\text { antiproliferative } \\
\text { activity against } \\
\text { MCF-7 and also, } \\
\text { DNA protective } \\
\text { activity against DNA } \\
\text { damage. }\end{array}$ & $\begin{array}{l}\text { The antiproliferative } \\
\text { potential of the extract } \\
\text { against breast cancer } \\
\text { cell lines may be due } \\
\text { to its strong } \\
\text { antioxidant potential. } \\
\text { Therefore, it is an } \\
\text { important functional } \\
\text { food. }\end{array}$ \\
\hline
\end{tabular}


Table 3. Summary of articles in this review: Hepatocellular cancer

\begin{tabular}{|c|c|c|c|c|c|}
\hline Author & Title & $\begin{array}{l}\text { Functional Food } \\
\text { Component }\end{array}$ & Methods & Results & Conclusion \\
\hline [48] & $\begin{array}{l}\text { Bioactivity evaluation } \\
\text { of a novel formulated } \\
\text { curcumin }\end{array}$ & Curcumin & $\begin{array}{l}\text { Cultured HCC cell lines were } \\
\text { treated with curcumin and the } \\
\text { formulated curcumin at different } \\
\text { concentrations for proliferation } \\
\text { and viability test. }\end{array}$ & $\begin{array}{l}\text { Curcumin and the } \\
\text { formulated curcumin } \\
\text { were effective in inducing } \\
\text { apoptosis through } \\
\text { mitochondria dysfunction } \\
\text { and also decreasing } \\
\text { proliferation and viability } \\
\text { of HCC cell lines in a dose- } \\
\text { dependent manner. }\end{array}$ & $\begin{array}{l}\text { Formulated } \\
\text { curcumin has the } \\
\text { same anticancer } \\
\text { activity as the } \\
\text { conventional } \\
\text { curcumin. }\end{array}$ \\
\hline [49] & $\begin{array}{l}\text { Characterization and } \\
\text { inception of a } \\
\text { triterpenoid } \\
\text { astrakurkurol, as a } \\
\text { cytotoxic molecule on } \\
\text { human hepatocellular } \\
\text { carcinoma cells, } \\
\text { Hep3B }\end{array}$ & Astrakurkurol & $\begin{array}{l}\text { Isolated and purified astrakurkurol } \\
\text { from the basidiocarp of Astraeus } \\
\text { hygrometricus was treated with } \\
\text { cell Hep3B in a WST-1 cell } \\
\text { proliferation assay followed by } \\
\text { cell survival, apoptosis assay etc. }\end{array}$ & $\begin{array}{l}\text { Significant decrease in } \\
\text { Hep3B cell viability and } \\
\text { induction of apoptosis } \\
\text { suggested by DNA } \\
\text { fragmentation, nuclear } \\
\text { shrinkage and imbalance } \\
\text { of cell cycle distribution }\end{array}$ & $\begin{array}{l}\text { Astrakurkurol, a } \\
\text { triterpenoid is a } \\
\text { natural source for a } \\
\text { safer cytotoxic drug } \\
\text { against } \\
\text { hepatocellular } \\
\text { carcinoma. }\end{array}$ \\
\hline$[50]$ & $\begin{array}{l}2^{\prime}, 4^{\prime}-\text { Dihydroxy-6'- } \\
\text { methoxy-3',5'- } \\
\text { dimethylchalcone } \\
\text { induced apoptosis and } \\
\text { G1 cell cycle arrest } \\
\text { through PI3K/AKT } \\
\text { pathway in BEL- } \\
7402 / 5-F U \text { cells }\end{array}$ & $\begin{array}{l}2^{\prime}, 4^{\prime}-\text { Dihydroxy-6'- } \\
\text { methoxy-3',5'- } \\
\text { dimethylchalcone } \\
\text { (DMC) }\end{array}$ & $\begin{array}{l}\text { HCC multi-drug resistant cell line } \\
\text { BEL-7402/5-FU was cultured, DMC } \\
\text { was isolated and purified by HPLC. } \\
\text { Cells were seeded and treated } \\
\text { with DMC using MTT technique to } \\
\text { assay for cell viability. ROS level } \\
\text { was measured and apoptosis } \\
\text { determined. }\end{array}$ & $\begin{array}{l}\text { Induction of apoptosis } \\
\text { predominantly via the } \\
\text { mitochondria-dependent } \\
\text { pathway, induction of cell } \\
\text { cycle arrest at G1 and } \\
\text { enhancement and } \\
\text { generation of reactive } \\
\text { oxygen species (ROS) }\end{array}$ & $\begin{array}{l}\text { DMC mediated } \\
\text { apoptosis and } \\
\text { arrest of G1 cell } \\
\text { cycle phase, this } \\
\text { presents it as a } \\
\text { potential natural } \\
\text { therapeutic agent } \\
\text { against HCC. }\end{array}$ \\
\hline [51] & $\begin{array}{l}\text { Quercetin inhibits } \\
\text { growth of } \\
\text { hepatocellular } \\
\text { carcinoma by } \\
\text { apoptosis induction in } \\
\text { part via autophagy } \\
\text { stimulation in mice }\end{array}$ & Quercetin (QCT) & $\begin{array}{l}\text { The effect of QCT on human } \\
\text { hepatoma cell lines SMMC7721 } \\
\text { and HepG2, cell growth was } \\
\text { determined by using the CCK-8 } \\
\text { assay followed by cell apoptosis } \\
\text { analysis by flow cytometry, } \\
\text { western blot for protein } \\
\text { determination and in vivo animal } \\
\text { studies. }\end{array}$ & $\begin{array}{l}\text { Inhibition of growth of } \\
\text { human HCC cells in dose- } \\
\text { and time-dependent } \\
\text { manner, increase in both } \\
\text { autophagosomes and } \\
\text { autolysosomes in HCC cell } \\
\text { and stimulation of } \\
\text { autophagy }\end{array}$ & $\begin{array}{l}\text { Autophagy } \\
\text { stimulation may be } \\
\text { an important } \\
\text { mechanism by } \\
\text { which Quercetin } \\
\text { and other } \\
\text { functional foods } \\
\text { induce cancer cell } \\
\text { apoptosis. }\end{array}$ \\
\hline [52] & $\begin{array}{l}\text { Licochalcone A from } \\
\text { licorice root, an } \\
\text { inhibitor of human } \\
\text { hepatoma cell growth } \\
\text { via induction of cell } \\
\text { apoptosis and cell } \\
\text { cycle arrest. }\end{array}$ & $\begin{array}{l}\text { Licochalcone A } \\
\text { (LCA) }\end{array}$ & $\begin{array}{l}\text { Extraction of licorice root with } \\
\text { ethanol followed by purification of } \\
\text { LCA then testing the effect on } \\
\text { cancer cell apoptosis. }\end{array}$ & $\begin{array}{l}\text { LCA inhibited the } \\
\text { proliferation of HepG2 } \\
\text { cells significantly, } \\
\text { affecting its growth by } \\
\text { terminating cell cycle at } \\
\text { G2/M transition. }\end{array}$ & $\begin{array}{l}\text { This research helps } \\
\text { us in recognizing } \\
\text { LCA as a promising } \\
\text { candidate for } \\
\text { induction of } \\
\text { apoptosis in human } \\
\text { hepatoma } \\
\text { carcinoma cells. }\end{array}$ \\
\hline$[53]$ & $\begin{array}{l}\text { Ginger } \\
\text { polysaccharides } \\
\text { induced cell cycle } \\
\text { arrest and apoptosis in } \\
\text { human hepatocellular } \\
\text { carcinoma HepG2 cells }\end{array}$ & $\begin{array}{l}\text { Ginger } \\
\text { polysaccharide (GP) }\end{array}$ & $\begin{array}{l}\text { Extraction of pure ginger } \\
\text { polysaccharide, and treatment } \\
\text { with cultured HepG } 2 \text { cells in MTT } \\
\text { assay for measurement of cell } \\
\text { viability. Hoechst } 33258 \text { apoptosis } \\
\text { detection kit was used to measure } \\
\text { apoptotic nuclear morphology } \\
\text { followed by flow cytometry. }\end{array}$ & $\begin{array}{l}\text { GP had significant } \\
\text { antitumor effect against } \\
\text { HCC, flow cytometry } \\
\text { suggested that GP } \\
\text { promotes apoptosis and } \\
\text { arrest cell cycle in G0-G1 } \\
\text { phase. }\end{array}$ & $\begin{array}{l}\text { GP can provide low- } \\
\text { cost anti- cancer } \\
\text { drug and become a } \\
\text { significant } \\
\text { functional food. }\end{array}$ \\
\hline [54] & $\begin{array}{l}\text { Antrodia cinnamomea } \\
\text { boosts the anti- } \\
\text { tumour activityof } \\
\text { sorafenib in xenograft } \\
\text { models of human } \\
\text { hepatocellular } \\
\text { carcinoma }\end{array}$ & $\begin{array}{l}\text { Extract of Antrodia } \\
\text { cinnamomea (EAC) }\end{array}$ & $\begin{array}{l}\text { Cultvation of } A \text { cinnamonea and } \\
\text { seeding in M } 25 \text { medium followed } \\
\text { by extraction and purification of } \\
\text { active compound by HPLC. MTT } \\
\text { assay was used to assess the } \\
\text { effect of sorafenib and EAC on } \\
\text { liver cancer cell viability. }\end{array}$ & $\begin{array}{l}\text { EAC dose-dependently } \\
\text { sensitized HepG } 2 \text { cells to } \\
\text { sorafenib-induced cell } \\
\text { death mediated through } \\
\text { targeting MAP kinases, } \\
\text { modulating cyclin } \\
\text { proteins expression and } \\
\text { inhibiting cancer cell } \\
\text { invasion. }\end{array}$ & $\begin{array}{l}\text { EAC can boost the } \\
\text { activity of sorafenib } \\
\text { on HCC cells. } \\
\text { However, more in } \\
\text { vivo investigation is } \\
\text { needed before the } \\
\text { EAC/Sorafenib } \\
\text { combination } \\
\text { assume clinical } \\
\text { application. }\end{array}$ \\
\hline
\end{tabular}




\begin{tabular}{|c|c|c|c|c|c|}
\hline Author & Title & $\begin{array}{l}\text { Functional Food } \\
\text { Component }\end{array}$ & Methods & Results & Conclusion \\
\hline$[55]$ & $\begin{array}{l}\text { Sesamol Induces } \\
\text { Human Hepatocellular } \\
\text { Carcinoma Cells } \\
\text { Apoptosis by Impairing } \\
\text { Mitochondrial } \\
\text { Function and } \\
\text { Suppressing } \\
\text { Autophagy }\end{array}$ & Sesamol & $\begin{array}{l}\text { HepG2 cells were cultured, seeded } \\
\text { and incubated in the presence or } \\
\text { absence of various concentrations } \\
\text { of sesamol for } 24 \mathrm{~h} \text { to observe the } \\
\text { colony formation. }\end{array}$ & $\begin{array}{l}\text { Suppression of colony } \\
\text { formation, arresting cell } \\
\text { cycle at S phase, inducing } \\
\text { apoptosis and loss of } \\
\text { mitochondrial membrane } \\
\text { potential. }\end{array}$ & $\begin{array}{l}\text { Sesamol is a } \\
\text { nutritional phenolic } \\
\text { antioxidant } \\
\text { compound which is } \\
\text { an effective inducer } \\
\text { of apoptosis by } \\
\text { impairing } \\
\text { mitochondria in } \\
\text { hepatocellular } \\
\text { carcinoma in } \\
\text { vitro and in vivo }\end{array}$ \\
\hline$[56]$ & $\begin{array}{l}\text { Athyrium } \\
\text { multidentatum (Doll.) } \\
\text { Ching extract induce } \\
\text { apoptosis via } \\
\text { mitochondrial } \\
\text { dysfunction and } \\
\text { oxidative stress in } \\
\text { HepG2 cells }\end{array}$ & Chlorogenic acid & $\begin{array}{l}\text { Collection of Athyrium } \\
\text { multidentatum Ching (AMC) and } \\
\text { extraction/purification of } \\
\text { bioactive compounds, Hep G2 and } \\
\text { HL7702 Cell viability was } \\
\text { determined using the MTT assay. }\end{array}$ & $\begin{array}{l}\text { Inhibition of cell growth, } \\
\text { induction of apoptosis } \\
\text { through intrinsic and } \\
\text { extrinsic pathways and } \\
\text { cell cycle arrest in HepG2 } \\
\text { cells }\end{array}$ & $\begin{array}{l}\text { The study provides } \\
\text { a new option for } \\
\text { the diet of } \\
\text { hepatocellular } \\
\text { carcinoma } \\
\text { susceptible } \\
\text { patients. }\end{array}$ \\
\hline$[57]$ & $\begin{array}{l}\text { Preparation of Prunella } \\
\text { vulgaris polysaccharide- } \\
\text { zinc complex and its } \\
\text { antiproliferative activity } \\
\text { in HepG } 2 \text { cells }\end{array}$ & $\begin{array}{l}\text { Prunella vulgaris } \\
\text { polysaccharide- } \\
\text { zinc complex (P1- } \\
\text { Zn) }\end{array}$ & $\begin{array}{l}\text { Extraction and } \\
\text { purification of extract } \\
\text { from P. vulgaris. MTT } \\
\text { assay for cell viability in } \\
\text { HepG2 cell lines } \\
\text { followed by flow } \\
\text { cytometry, caspase } \\
\text { assay e.t.c }\end{array}$ & $\begin{array}{l}\text { Inhibition of proliferation } \\
\text { of HepG } 2 \text { cells at } 98.4 \% \\
\text { inhibition rate at } 500 \\
\mu \mathrm{g} / \mathrm{mL} \text { through induction } \\
\text { of apoptosis (activation of } \\
\text { caspase- } 3 \text { and }-9 \text { and } \\
\text { mitochondrial } \\
\text { dysfunction) }\end{array}$ & $\begin{array}{l}\text { P1-Zn may be a } \\
\text { potent candidate } \\
\text { for human } \\
\text { hepatocellular } \\
\text { carcinoma } \\
\text { prevention and } \\
\text { treatment in the } \\
\text { field of functional } \\
\text { foods }\end{array}$ \\
\hline$[58]$ & $\begin{array}{l}\text { Antioxidant and } \\
\text { Antitumor Activities of } \\
\text { the Extracts from } \\
\text { Chinese Yam } \\
\text { (Dioscorea opposite } \\
\text { Thunb.) Flesh and Peel } \\
\text { and the Effective } \\
\text { Compounds }\end{array}$ & $\begin{array}{l}\text { Gallic acid, } \\
\text { chlorogenic acid, } \\
\text { vanillic acid, } \\
\text { syringic acid, } \\
\text { epicatechin,p- } \\
\text { coumaric acid, } \\
\text { phlorizin, ferulic } \\
\text { acid, rutin, } \\
\text { quercetin and } \\
\text { kaempferol }\end{array}$ & $\begin{array}{l}\text { Kunming mice were injected with } \\
\text { tumor cells of H22. Extract } \\
\text { solution of peel and flesh was } \\
\text { given to mice and anti-tumor } \\
\text { capacity was assayed. }\end{array}$ & $\begin{array}{l}\text { Water and ethanol } \\
\text { extracts isolated from } \\
\text { Chinese yam (Dioscorea } \\
\text { opposite Thunb.) flesh } \\
\text { (CYF) and peel (CYP) has } \\
\text { antitumor property } \\
\text { against hepatocarcinoma } \\
\text { tumor (H22) model }\end{array}$ & $\begin{array}{l}\text { Functional food } \\
\text { components have } \\
\text { been acknowledged } \\
\text { as an important } \\
\text { determinant in } \\
\text { cancer prevention. } \\
\text { Studies should } \\
\text { focus on studying } \\
\text { the specific } \\
\text { mechanism exerted } \\
\text { by each bioactive } \\
\text { component }\end{array}$ \\
\hline [59] & $\begin{array}{l}\text { Antioxidant and in } \\
\text { vitro anticancer } \\
\text { activities of } \\
\text { phenolics isolated } \\
\text { from sugar beet } \\
\text { molasses }\end{array}$ & $\begin{array}{l}\text { Gallic acid, } \\
\text { cyanidin-3-O- } \\
\text { glucoside chloride } \\
\text { (CGC) and } \\
\text { epicatechin. }\end{array}$ & $\begin{array}{l}\text { Extraction of sugar beet molasses } \\
\text { followed by identification and } \\
\text { purification of active components } \\
\text { using HPLC and spectrometry } \\
\text { techniques. Anti-tumor activity } \\
\text { against hepatocellular (HepG2) } \\
\text { done using MTT assay. }\end{array}$ & $\begin{array}{l}\text { Inhibitory activity against } \\
\text { hepatocellular (HepG2) } \\
\text { cell lines. }\end{array}$ & $\begin{array}{l}\text { SBM as a strong } \\
\text { anti-tumor can be } \\
\text { helpful in preparing } \\
\text { functional foods } \\
\text { against } \\
\text { hepatocellular } \\
\text { carcinoma. }\end{array}$ \\
\hline [60] & $\begin{array}{l}\text { Involvement of } \\
\text { autophagy induction } \\
\text { in penta-1,2,3,4,6-O- } \\
\text { galloyl- } \beta-D-\text {-glucose- } \\
\text { like growth arrest in } \\
\text { human cancer cells }\end{array}$ & $\begin{array}{l}\text { Penta-1,2,3,4,6-O- } \\
\text { galloyl- } \beta \text {-D-glucose } \\
\text { (PGG) }\end{array}$ & $\begin{array}{l}\text { PGG was prepared through acidic } \\
\text { methanolysis of tannic acid after } \\
\text { which purity was established. } \\
\text { hepG } 2 \text { cells were treated with } 25 \\
\mu \mathrm{M} \text { PGG, seeded and cultured to } \\
\text { evaluate the proliferative } \\
\text { capacity. }\end{array}$ & $\begin{array}{l}\text { Induction of autophagy } \\
\text { and senescence in vitro in } \\
\text { HepG } 2 \text { and in vivo in a } \\
\text { xenograft mouse model } \\
\text { of human HepG } 2 \text { liver } \\
\text { cancer. }\end{array}$ & $\begin{array}{l}\text { PGG is a } \\
\text { chemopreventive } \\
\text { polyphenolic } \\
\text { compound, } \\
\text { effective against } \\
\text { hepatocellular and } \\
\text { other forms of } \\
\text { human cancers. }\end{array}$ \\
\hline
\end{tabular}


Table 4. Anticancer Mechanism of Functional Food Components in Cervical Cancer

\begin{tabular}{|c|c|c|c|}
\hline $\begin{array}{l}\text { Foods, Plant crude extracts, } \\
\text { Fruits, Natural Products, etc. }\end{array}$ & Compounds & Anti-cancer Mechanism & References \\
\hline Lycium barbarum fruit & Arabinogalactan & $\begin{array}{l}\text { - Induction of apoptosis. } \\
\text { - } \text { Downregulation of } \mathrm{Bcl}-2 / \mathrm{Bax} \text { expression. } \\
\text { - } \quad \text { Upregulation of Caspase-3,8 and } 9 \text {. } \\
\text { - } \text { Cell cycle arrest at } \mathrm{G}_{0} / \mathrm{G}_{1} \text { phase. } \\
\text { - } \text { ROS generation. } \\
\text { - }\end{array}$ & {$[25]$} \\
\hline Lycium barbarum fruit & $\begin{array}{l}\text { Lycium barbarum } \\
\text { Polysaccharide (LBP) }\end{array}$ & $\begin{array}{l}\text { - } \quad \text { Cell cycle arrest at S-phase. } \\
\text { - Increase in intracellular } \mathrm{Ca}^{2+} \text { ion. } \\
\text { - Induction of apoptosis. }\end{array}$ & {$[36]$} \\
\hline Polygonatum sibiricum & Methyl Protodioscin & $\begin{array}{l}\text { - Alteration of cell morphology with } \\
\text { - } \quad \text { cell cycle arrest at G2/M phase. } \\
\text { - Induce apoptosis. }\end{array}$ & {$[26]$} \\
\hline Dietary Phytosterol Ingredients & $\beta$-sitosterol & $\begin{array}{l}\text { - } \quad \text { Cell cycle arrest at } \mathrm{S} \text { and } \mathrm{G}_{2} / \mathrm{M} \text { phase. } \\
\text { - Induction of apoptosis. }\end{array}$ & {$[27]$} \\
\hline Salvia miltiorrhiza burge & 15,16-Dihydrotanshinone & $\begin{array}{l}\text { - Regulation of TNF- } \alpha \text { expression. } \\
\text { - } \quad \text { Cell cycle arrest at } \mathrm{G}_{2} / \mathrm{M} \text { phase. }\end{array}$ & {$[28]$} \\
\hline Artemisia herba alba & $\begin{array}{l}\text { Caffeoylquinic acid and } \\
\text { sesquiterpene lactone }\end{array}$ & $\begin{array}{l}\text { - } \quad \text { Production of ROS. } \\
\text { - Induction of apoptosis. }\end{array}$ & [29] \\
\hline Mulberry & Morin & $\begin{array}{l}\text { - } \quad \text { Alteration of cell morphology. } \\
\text { - } \quad \text { Induction of apoptosis. } \\
\text { - Upregulation of p53, p21 and Wee1 } \\
\text { expressions. } \\
\text { - Downregulation of CDK1, Cdc25c, } \\
\text { surviving, cyclin B1, CHK2. } \\
\text { - Cell cycle arrest. }\end{array}$ & {$[30]$} \\
\hline Citrus grandis leaf & $\begin{array}{l}\text { Isosnensetin, sinensetin, } \\
\text { tetramethyl-O-isoscutellarein, } \\
\text { nobiletin, tangeretin and 5- } \\
\text { hydroy- } 6,7,8,3^{\prime}, 4^{1} \text { - } \\
\text { pentamethoxyflavone }\end{array}$ & $\begin{array}{l}\text { - } \quad \text { Apoptosis. } \\
\text { - } \quad \text { Biminished expression of anti-apoptotic } \\
\text { - Proteolytic activation of caspase cascade. } \\
\text { - } \quad \text { Destruction of PARP. }\end{array}$ & {$[38]$} \\
\hline Hazelnut shell & $\begin{array}{l}\text { neolignans, lawsonicin, } \\
\text { cedrusin, balanophonin, gallic } \\
\text { acid, phenolic derivatives, } \\
\text { dihydroconiferyl alcohol, } \\
\text { veratric acid, vanillic acid and } \\
\text { carpinontriol }\end{array}$ & $\begin{array}{l}\text { - Activation of caspase-3. } \\
\text { - Induction of apoptosis }\end{array}$ & {$[32]$} \\
\hline Wheat & $\begin{array}{l}\text { Caffeic acid, vanillic acid, } \\
\text { syringic acid, ferulic acid and } \\
\text { coumaric }\end{array}$ & & {$[80]$} \\
\hline $\begin{array}{l}\text { Red rice bran } \\
\text { Ginger }\end{array}$ & $\begin{array}{l}\text { Proanthocyanin. } \\
\text { poly-phenols and flavones- } \\
\text { flavanols }\end{array}$ & $\begin{array}{ll} & \text { Cytotoxicity } \\
\text { - } & \text { Apoptosis } \\
\text { - } & \text { Disruption of microtubular network. } \\
\text { - } & \text { Alteration of cell morphology. } \\
\text { - } & \text { Cell cycle arrest at sub } \mathrm{G}_{0} / \mathrm{G}_{1} \text {. }\end{array}$ & {$[35,37]$} \\
\hline
\end{tabular}


Table 5. Anticancer Mechanism of Functional Food Components in Breast Cancer

\begin{tabular}{|c|c|c|c|}
\hline $\begin{array}{l}\text { Foods, Plant crude extracts, } \\
\text { Fruits, Natural Products, etc. }\end{array}$ & Compounds & Anti-cancer Mechanism & References \\
\hline Dwarf lilyturf tuber & $\begin{array}{l}\text { Dwarf-lillytruf tuber } \\
\text { monomer-13 (DT-13) }\end{array}$ & $\begin{array}{l}\text { - Inhibition of Tumour } \\
\text { - } \text { Metastasis. } \\
\text { - } \text { Restriction of cell polarity. } \\
\text { dependent cell migration. }\end{array}$ & [39] \\
\hline Diary product; Butter & $\begin{array}{l}\text { c9,t11-conjugated } \\
\text { linoleic acid (CLA }\end{array}$ & $\begin{array}{l}\text { - } \quad \text { Downregulation of ER, PR } \\
\text { - } \quad \text { Inhibition of cell proliferation. } \\
\text { - } \quad \text { Pro-apoptotic effect. } \\
\text { - } \quad \text { Activation of Caspase } 3 \text { and } 9 .\end{array}$ & {$[40]$} \\
\hline Lycium barbarum fruit & Arabinogalactan & $\begin{array}{l}\text { - Cell cycle arrest at Go/G1 } \\
\text { phase. } \\
\text { - Upregulation of Caspase-3,8 } \\
\text { and } 9 . \\
\text { - } \text { ROS generation. } \\
\text { - Downregulation of Bcl-2/Bax } \\
\text { expression. } \\
\text { - Activation of MAP Kinase } \\
\text { signaling pathway }\end{array}$ & {$[25]$} \\
\hline Soy bean & Genistein & $\begin{array}{l}\text { Down-regulation of GPR30 } \\
\text { expression. } \\
\text { - Inhibition of Akt } \\
\text { phosphorylation. } \\
\text { - Reduced expression of cyclin } \\
\text { D1. }\end{array}$ & {$[41]$} \\
\hline Syzygium aromaticum & $\begin{array}{l}\text { Phenolic acid, flavonol } \\
\text { glucoside, tannins and } \\
\text { phenolic volatile oils }\end{array}$ & $\begin{array}{l}\text { Pro-apoptotic effect. } \\
\text { - Upregulation of p53, Caspase-3 } \\
\text { and } 7 . \\
\text { - Altered mitochondrial } \\
\text { potential. } \\
\text { - Downregulation of expression } \\
\text { of Bcl-2, COX-2, cMyc and H- } \\
\text { ras. }\end{array}$ & [44] \\
\hline $\begin{array}{l}\text { Red pitaya } \\
\text { (Hylocereus polyrhizus) }\end{array}$ & Anthocyanin & $\begin{array}{l}\text { - } \\
\text { Suppressed expression of } \\
\text { BRCA1, BRCA2, PRAB, and Er } \boldsymbol{\alpha} \text {. } \\
\text { - Induction of apoptosis. } \\
\text { - Increase in G0/G1 phase } \\
\text { - } \text { Decrease in G2/M phase. }\end{array}$ & {$[45]$} \\
\hline Petroselinum crispum & Crude extract & $\begin{array}{l}\text { - Inhibition of cell migration. } \\
\text { - Protection against DNA } \\
\text { damage. }\end{array}$ & {$[47]$} \\
\hline
\end{tabular}


Table 6. Anticancer Mechanism of Functional Food Components in Hepatocarcinoma

\begin{tabular}{|c|c|c|c|}
\hline $\begin{array}{l}\text { Foods, Plant crude extracts, } \\
\text { Fruits, Natural Products, etc. }\end{array}$ & Compounds & Anti-cancer Mechanism & References \\
\hline Curcuma long. & Curcumin & $\begin{array}{l}\text { - Induction of apoptosis. } \\
\text { - Activation of Caspase-3 } \\
\text { - Inhibition of NF-KB. }\end{array}$ & {$[48]$} \\
\hline Astraeus hygromtricus & Astrakurkurol & $\begin{array}{l}\text { - } \text { Cell cycle at the G0/G1 phase } \\
\text { - Induction of Apoptosis } \\
\text { - } \text { Activation of caspase-8 and } \\
\text { - } \text { Ins protein } \\
\text { pathwibition Akt and NF-KB }\end{array}$ & [49] \\
\hline Cleistocalyx operculatus & $\begin{array}{l}2^{\prime}, 4^{\prime} \text {-Dihydroxy-6'-methoxy-3', } 5^{\prime} \text { - } \\
\text { dimethylchalcone (DMC) }\end{array}$ & 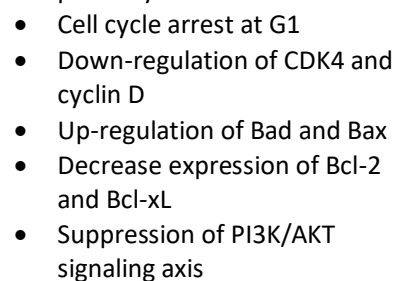 & {$[50]$} \\
\hline \multirow[t]{2}{*}{ Glycyrrhiza inflate } & Licochalcone A & $\begin{array}{l}\text { Increase mRNA expression of } \\
\text { DR3, DR5, caspases-3, } 8 \text { and } \\
\text { 9, Fas, Bad, Bax and } \mathrm{BCl}-2 \text {. } \\
\text { Cell cycle arrest at } \mathrm{G} 2 / \mathrm{M} \\
\text { transition }\end{array}$ & {$[52]$} \\
\hline & Quercetin & $\begin{array}{l}\text { - Induction of autophagy } \\
\text { - Inhibition of AKT/mTOR } \\
\text { pathway } \\
\text { - Activation of MAPK pathway }\end{array}$ & {$[51]$} \\
\hline Athyrium multidentatum & Chlorogenic acid & $\begin{array}{l}\text { - Induction of Apoptosis } \\
\text { - Modulation of NFKB, } \\
\text { MAPK/ERK and PI3K/Akt } \\
\text { pathways }\end{array}$ & {$[56]$} \\
\hline $\begin{array}{l}\text { Ginger rhizomes, Zingiber } \\
\text { officinale Roscoe }\end{array}$ & Ginger polysaccharide & $\begin{array}{l}\text { - Induction of Apoptosis } \\
\text { - Cell cycle arrest at the G0-G1 } \\
\text { phase } \\
\text { - Increase expression of Bax, } \\
\text { - Fas, p53, and caspase-3 } \\
\text { - Decrease expression of Bcl-2 }\end{array}$ & {$[53]$} \\
\hline Sesame seed & Sesamol & $\begin{array}{l}\text { - Induction of Apoptosis } \\
\text { - Suppression of colony } \\
\text { formation } \\
\text { - Cell cycle at S phase }\end{array}$ & {$[55]$} \\
\hline Prunella vulgaris & $\begin{array}{l}\text { Prunella vulgaris polysaccharide- } \\
\text { zinc complex }\end{array}$ & $\begin{array}{l}\text { - Induction of Apoptosis } \\
\text { - Activation of caspase-3 and } \\
\text { caspase- } 9\end{array}$ & {$[57]$} \\
\hline Antrodia cinnamomea & $\begin{array}{l}\text { Methyl antcinate B, } \\
\text { Dehydroeburicoic acid, } 15 \alpha \text { - } \\
\text { acetyl dehydrosulphurenic acid, } \\
\text { Zhankuic acid C and Antcin A, C } \\
\text { and K }\end{array}$ & $\begin{array}{l}\text { - Mediation of cell death } \\
\text { - MAP kinase pathway } \\
\text { activation } \\
\text { - Modulation of cyclin proteins } \\
\text { expression }\end{array}$ & {$[54]$} \\
\hline $\begin{array}{l}\text { Dioscorea opposite Thunb. } \\
\text { (Chinese yam) }\end{array}$ & $\begin{array}{l}\text { gallic acid, chlorogenic acid, } \\
\text { vanillic acid, epicatechin, } \\
\text { coumaric acid, phlorizin, ferulic } \\
\text { acid, rutin, quercetin and } \\
\text { kaempferol. }\end{array}$ & & {$[58]$} \\
\hline sugar beet molasses (SBM) & $\begin{array}{l}\text { Gallic acid, cyanidin-3-O- } \\
\text { glucoside chloride (CGC) and } \\
\text { epicatechin. }\end{array}$ & & [59] \\
\hline
\end{tabular}




\subsection{DISCUSSION}

Cancer is a disease of ageing that remains a significant cause of death globally in rank following cardiovascular disease [62]. Deaths resulting from various types of cancer continue to rise. In the United States, the American Cancer Society had estimated 13,800, 42,810 and 279,100 new cases of cervical, liver, and breast cancer respectively with an estimated 4,290, 30,160 and 42,690 deaths resulting from cervical, liver, and breast cancer respectively [63]. Therefore, there is an increasing need to curtail the malady: cancer that is ravaging all age groups, genders, and race of the global populace. However, the current therapeutic strategy is challenged by multiple organ toxicity [62] and such low efficacy of drugs led to the discovery of natural compounds with the ability to prevent and manage cancer [64].

4.1 Functional Food and Cervical Cancer: In this review, there are about thirty (30) compounds or classes of compounds reported to actively hamper growth in human cervical cell models. These compounds are functional food components found in plant products.

4.1.1 Arabinogalactan: Arabinogalactan is a potent immunomodulatory agent. In this review, Gong et al [26] reportedly purified this compound from Lycium barbarum fruit. It was reported to be the most potent anti-tumor agent among the 3 polysaccharide fractions (LBGP-I-3) purified in the same study. Arabinogalactan repressed growth in human cervical cancer with $55.94 \%$ cell viability following MTT assay at $800 \mathrm{ug} / \mathrm{ml}$ in $24 \mathrm{hrs}$ treatment. The anti-cancer mechanism is linked to the ability of arabinogalactan to induce apoptosis by downregulating the expression of $\mathrm{Bcl}-2 / \mathrm{Bax}$ and upregulating Caspase-3, 8, and 9. Disruption of the heterodimeric $\mathrm{Bcl}-2 / \mathrm{Bax}$ is critical to the release of cytochrome $\mathrm{c}$ and this represents a significant event in apoptosis [65]. Therefore, the ability of arabinogalactan to downregulate $\mathrm{Bcl}-2 / \mathrm{Bax}$ is a probable mechanism that punctuates its anti-proliferative potential in cervical HeLa cells, although this compound was also shown to induce cell cycle arrest at $\mathrm{G}_{0} / \mathrm{G}_{1}$ phase, ROS generation, and activation of MAP Kinase signaling shunt [26].

Other than arabinogalactan, other functional foods have been isolated from the Chinese medicinal herb Lycium barbarum fruit with effective anti-cancer properties. For instance, the isolation of Lycium barbarum Polysaccharide (LBP) has been reported. Our data showed that this compound can also inhibit the proliferation of HeLa cells. In fact, data from cytometric analysis indicated that LBP disrupts cell cycle progression at S-phase. In the same study, there was an increase in intracellular $\mathrm{Ca}^{2+}$ ions, this put together with the ability of LBP to induce apoptosis may underline its anti-tumor potential [37].

4.1.2 Methyl Protodioscin (MPD): Methyl Protodioscin is enriched with high content saponin from the rhizome of Polygonatum sibiricum. Data from $\mathrm{Ma}$ and colleagues [27] showed that MPD hampered proliferation in the human cervical cancer cell line with altered morphology - pseudopod extension. The anti-cancer capacity of MPD was correlated to its ability to arrest cell cycle progression at $\mathrm{G} 2 / \mathrm{M}$ phase and induce apoptosis via the death receptor pathway [27].

4.1.3 Phytosterol: $\beta$-sitosterol, campesterol, and stigmasterol are phytosterols. These compounds are common plant bioactive food components in diets [6667]. In this review, Alvarez-Sala et al [28] reported the effect of oil enriched with $\beta$-sitosterol on HeLa cell. This study demonstrated that $\beta$-sitosterol, induces cell cycle 
arrest at $\mathrm{S}$ and $\mathrm{G}_{2} / \mathrm{M}$ phase and decreases cell viability via induction of apoptosis [28].

4.1.4 15,16-Dihydrotanshinone (DI): The traditional Asian functional food Salvia miltiorrhiza Burge is enriched with DI and usually well distributed in the root of this plant. Studies have shown that DI repressed cell proliferation in cervical HeLa cells by regulating TNF- $\alpha$ expression [68]; although there is limitation to the anticancer activity of DI due to its low solubility in aqueous medium [69]. In recent times, the solubility of DI has been enhanced by liposomes, cyclodextrin inclusion, microemulsion, and nanoparticles [68,71-73]. Furthermore, the research demonstrated that the antitumor ability of DI can be improved by copolymer encapsulation. This study encapsulates DI with polylacticco-glycolic acid activated by polyethylene glycol (PPA) and PPA-conjugated biotin (BPA). The capsules were biophysically distributed by conjugation to nanoparticles. The DI-BPA-NPs polymer repressed cell growth in human cervical cancer cells through the arrest of cell cycle progression at $\mathrm{G}_{2} / \mathrm{M}$ phase [29].

\subsubsection{Ethyl acetate Fraction (EAF) of Artemisia herba}

alba: LC-ESI-TOF-MS and GC-EI-MS profiling of Artemisia herba alba unveiled the presence of numerous bioactive compounds. Bourgou and colleagues reported that the EAF is effective against cell proliferation in HeLa cell [30]. This is primarily due to the presence of cytotoxic compounds in EAF including caffeoylquinic acid derivatives such as di and tri-caffeoylquinic acid, napthoquinone derivatives [74], and santonin - a sesquiterpene lactone [75]. The mechanism of EAF anticancer activity is through the production of ROS and the induction of apoptosis via the mitochondria dependent pathway [30].
4.1.6 Morin : Many fruits and medicinal herbs contain the flavonoid morin [76]. Activity reports showed that morin is an effective anti-cancer agent in breast cancer, oral tumour, colon, and liver cancers [31,77-80]. In human cervical cancer cells, morin altered cell morphology and markedly diminished survival rate by inducing programmed cell death through the death receptor pathway. Also, in the same study, morin treatment incited the sustained expression of $p 53, p 21$ and Wee1 and caused the downregulation of CDK1, Cdc25c, survivin, cyclin B1, and CHK2 thereby culminating in cell cycle halt [31].

4.1.7 Citrus grandis Leaf Extract: The chloroform fraction of Citrus grandis leaf extract strongly reduces cell viability in human cervical cancer cells via apoptosis. The major apoptotic mechanism elicited is by the ability of the extract to diminish the expression of anti-apoptotic $\mathrm{Bcl}-2$ and subsequent proteolytic activation of caspase cascade, thus leading to the destruction of poly (ADPribose) polymerase (PARP). Chromatographyelectrospray ionization tandem mass spectrometry (LCESI-MS/MS) has revealed the bioactive component of the leaf extract, and this includes: isosnensetin, sinensetin, tetramethyl-O-isoscutellarein, nobiletin, tangeretin and 5-hydroy-6,7,8,3',41-pentamethoxyflavone [39].

4.1.8 Others: There are several other natural sources abundantly replenished with functional food components that are anticancer agents. In this review, we present the work of Esposito and his colleague on Hazelnut shell extract (HSE) [33]. They found out that this extract contains neolignans, lawsonicin, cedrusin, balanophonin, gallic acid, phenolic derivatives, dihydroconiferyl alcohol, veratric acid, vanillic acid, and carpinontriol. These bioactive ingredients are reported to be responsible for the ability of HSE to hamper cell 
growth via caspase-3 mediated induction of apoptosis. In another study, the presence of flavonoids and phenolics has been tentatively correlated to inhibition of cell proliferation in HeLa cells [34]. A particular report adumbrated the presence of caffeic acid, vanillic acid, syringic acid, ferulic acid, and coumaric acid in wheat and showed that these bioactive compounds are responsible for the anti-tumor action of wheat [81].

A comparative study of the chemical composition and bioactive properties of Ganoderma lucidum from two sources - Serbia; China - revealed that Ganoderma lucidum cultivated in Serbia exhibit anti-tumor effect in HeLa cells [35]. In another comparative study, HPLC-PDA aided isolation, punctuating the relative abundance of phenolics, anthocyanin, and proanthocyanin content in brown, purple, and red rice brans. The same study identified the abundance of proanthocyanin in red rice bran and showed that such high amounts may be responsible for its anticancer property [36].

The ability of many functional foods to alter cell morphology has been correlated to the presence of active component capable of disrupting network of microtubules in cancer cells. The Folin-Ciocalteu assay revealed the presence of polyphenols and flavonesflavanols in ginger aqueous extract. The extract disrupted microtubular network leading to altered cell morphology and cell cycle arrest - sub $\mathrm{G}_{0} / \mathrm{G}_{1}$ - in cervical HeLa cells [38]. Table 4 below shows the overall mechanisms of functional food components in cervical cancer.

\subsection{Functional Food and Breast Cancer}

\subsubsection{Dwarf-lillytruf tuber monomer-13 (DT-13):}

Metastasis is one of the established hallmarks of cancer. The features of the tumor microenvironment are complex and interrelated. Dwarf-lilyturf tuber monomer13 (DT-13) possesses good potential against tumour microenvironment [40]. DT-13 is a saponin monomer extracted from dwarf lilyturf tuber, a member of subfamily Radix ophiopogonis which had been in use for centuries in Traditional Chinese Medicine (TCM). Previous studies have shown that DT-13 exerted remarkable effects on cancer cell migration, invasion, and metastasis [82-83]. In the work of Gao et al. [40], the anti-carcinogenic mechanism of DT-13 encompassed the inhibition of tumor metastasis in vitro via increasing expression of non-muscle myosin II-A (NMII-A) and its localization around the nucleus thus restricting its effect on the cell polarity [84]. Moreover, this has been closely associated with ERK/RAF/FAK/Paxillin signaling pathways in vitro. It was concluded from this study that DT-13 targeted NMII-A for the regulation of hypoxia-dependent cell migration through RAF, ERK, FAK and Paxillin signaling pathway.

\subsection{2 c9, t11-conjugated linoleic acid (CLA): Dietary}

sources of functional chemicals are also an explored area of interest to elucidate their anti-cancer properties. Conjugated linoleic acid (CLA) obtained from butter is the isomer of linoleic acid with conjugated double bonds. It has attracted scientific interest because of its anticancer, anti-obesity, and antiaging bioactivities [85-87]. CLA is naturally present in ruminant-derived products, such as milk, dairy, and beef products [87-88].

The mechanism of the anticancer effect of $c 9, t 11$ CLA involves reducing breast cancer progression by affecting the level of hormonal receptor and cell proliferation. Tang et al [41] has confirmed the preventive effect of the dietary $c 9, t 11$-CLA from butter against breast cancer in vivo. It was found that pretreatment with $c 9, t 11-C L A$ reduced the body weight significantly and reduced the tumor incidence to $50 \%$ as well as tumor weight and volume in 7,12dimethylbenz $(\alpha)$ anthracene-induced mammary cancer. Previous studies have demonstrated that $c 9, t 11-C L A$ has inhibitory and pro-apoptotic effects on MCF-7 breast 
cancer cells in vitro (90). Furthermore, Tang et al [41] found that the $c 9, t 11-C L A$ enriched from butter substantially demonstrated a preventive effect against breast cancer in vivo. However, the c9,t11-CLA enriched in their study contains a lot of other PUFA, which may affect the prophylactic capacity against cancer. Another mechanism shown is that dietary $c 9, t 11-C L A$ can significantly downregulate the hormonal receptor and has anti-proliferative effect against mammary cancer in vivo.

4.2.3 Arabinogalactan: Natural compounds with high efficacy, low toxicity, and minimal side effects attract the interest of researchers to explore Lycium barbarum, which belongs to the plant family Solanaceae, and it is a traditional medicine and food plant in China. L. barbarum fruit exhibits a variety of health-promoting activities including immunomodulation, anti-aging activity,antifatigue activity, anti-inflammatory activity, and inhibition of cancer cell growth [60, 91-92]. The underlying anticancer mechanism reported by Gong et al [26] suggested that LBGP-I-3 inhibited the growth of breast cancer cells by cell cycle arrest at the $G_{0} / G_{1}$ phase as well as altered mitochondrial potential.

4.2.4 Genistein: Studies have shown that the consumption of soy foods lowers the risk of breast cancer. Genistein is one of the most abundant isoflavones present in soybeans. It has a chemo preventive effect on mammary carcinogenesis [93-94]. The estrogen receptor (ER) whose alteration induced mammary cancer has been shown to be the target of genistein. This compound antagonizes ER to exert its anticarcinogenic and chemopreventive properties. In other studies, genistein was reported to block G2/M progression of the cancer cell cycle $(95,96)$. Zeng et al [41] reported that the anticancer mechanism of genistein against $B R C A 1$-silenced breast cancer cells resulted in the down-regulation of $\mathrm{G}$ protein-coupled receptor 30 (GPR30) expression and the inhibition of Akt phosphorylation as well as reduced cell viability, migration, and colony formation.

Chemoprevention was achieved by genistein through the inhibition of the growth and proliferation of Triple Negative Breast Cancer (TNBC) cells with mutant BRCA1 by targeting GPR30 via GPR30-Akt signaling, resulting in aggressiveness of TNBC cells. This led to the reduced expression of Akt, and subsequently cyclin B1, a key enzyme involved in cell cycle progression in the $\mathrm{G} 2 / \mathrm{M}$ phase. Furthermore, BRCA1-mutant breast cancer cells exhibited higher levels of intracellular ROS than those in the wild-type cells. Genistein treatment lowered the ROS levels through up-regulation of Nrf2 signaling.

4.2.5 Mungbean Vicilin Protein (MBVP): Functional foods are known to exert beneficial effects on human health in numerous ways. The natural plant-based principles are being explored as relatively more effective, safer and cost-effective preparations [97].

Mungbean (Vigna radiata) is one of the popular foods in India because of being a rich protein source. In a particular study, mungbean vicilin protein (MBVP), a hydrolysate was generated upon enzyme treatment alongside two other hydrolysates [43]. Vicilin is a major seed storage protein and contains bioactive peptides. Anti-proliferative activity of mungbean seed extracts and their hydrolysate on breast cancer cells MCF-7 and MDAMB-231 showed that among other hydrolysate, the MBVP showed significant anti-proliferative activity against both MCF-7 and MDA-MB-231 breast cancer cells at the doses between $0.2-1.0 \mathrm{mg} / \mathrm{ml}$. It was fascinating that, MBVP showed significant dose dependent antiproliferative effect against both cancer cells, with $50 \%$ 
inhibition observed after treating cells with $1 \mathrm{mg} / \mathrm{ml}$ of MBVP after $48 \mathrm{hrs}$.

4.2.6 Soy Isoflavone: Uifălean et al [44] used a global metabolomic study to compare the metabolome of two different breast cancer cell lines, MCF-7 and MDA-MB231, in response to studies on three soy isoflavones: genistein (Gen), daidzein (Dai) and a soy seed extract (Ext). Metabolomic study was carried out because isoflavones have different binding capacities and potencies [98]. A dose dependent effect was observed at high isoflavone doses (IC20) and anti-proliferative effects were seen on exposed MCF-7 and MDA-MB-231 cells. However, low isoflavone doses (SC20) induced estrogenlike effects by stimulating the cell proliferation of MCF-7 cells. Therefore, utilizing the correct dose and elucidating the multiple molecular mechanisms of isoflavones may be a powerful tool in mammary cancer chemoprevention and highlights how some foods may cause cancers to become worse.

\subsubsection{Phenolic acid, flavonol glucoside, tannins and} phenolic volatile oils: Lately, epidemiological studies reveal that long-term consumption of plant-derived functional foods is associated with a lower risk of breast carcinoma [99-101]. Dried flower buds of cloves (CLOs). CLOs (Syzygium aromaticum L.) are spices, which consist of a mixture of phytochemicals such as acids, flavonol, glucosides, tannins, and phenolic volatile oils. It has antiproliferative, anti-inflammatory, antibacterial, and antiseptic activities, which make this food a potentially suitable natural substance for cancer chemoprevention [102]. In a particular study, it was reported that CLO significantly inhibited the risk of mammary gland carcinomas in rats in a dose-dependent manner [45]. Differential doses of dietary administered CLO significantly decreased tumor frequency by $58.5 \%$ and $47.5 \%$ respectively compared to control rats.
4.2.8 Petroselinum crispum extract: The chemical composition and pharmacological properties of $P$. crispum have been previously reported in various studies. The herb contains flavonol glycosides of quercetin, apiol, myristicin, luteolin, terpenes, phthalides, furanocoumarins, apiin, carotenoids, ascorbic acid, and tocopherol [103-104]. It was reported that the dichloromethane extract of $P$. crispum leaves and stems showed antioxidant activities, inhibition of proliferation and cell migration in MCF-7 cells. The extract also protected against DNA damage induced by $\mathrm{H}_{2} \mathrm{O}_{2}$. Further, mouse fibroblasts (3T3-L1) pre-treated with $400 \mathrm{~mL}^{-1}$ of the extract showed $50.9 \%$ protection against $\mathrm{H}_{2} \mathrm{O}_{2-}$ induced DNA damage, suggesting its potential in cancer prevention. The extract ( 300 extract $\mathrm{mL}^{-1}$ ) inhibited $\mathrm{H}_{2} \mathrm{O}_{2}$ induced MCF-7 cell migration by $41 \% \pm 4 \%$. Thus, since cell migration is necessary for metastasis of cancer cells, inhibition of migration is an indication that $P$. crispum extract has the potential to hamper metastasis and prevent cancer progression. Table 5 below shows the overall mechanisms of functional food components in breast cancer

\subsection{Functional Food and Hepatocarcinoma}

4.3.1 Curcumin: Curcumin has been used widely as a functional food because of its pharmacological properties including its strong anticancer properties. It is a polyphenolic compound extracted from rhizomes of Curcuma longa, a plant which has been found to have strong antioxidant and anti-inflammatory effects [105106]. Liao et al [49] formulated curcumin pellets using solid dispersion techniques due to the limitations in the oral usage of curcumin as a food supplement because of its poor oral bioavailability. The biological functions of formulated curcumin were tested using C-Map and Library of Integrated Network-Based Cellular Signatures (LINCS) Unified Environment (CLUE) gene expression database. Formulated curcumin and the conventional type significantly inhibited HCC cell lines Huh7, Mahlavu, and PLC5 in MTT assay. In addition, conventional and formulated curcumin separately induced apoptosis by activating caspase-3 and potently inhibited NF-KB. 
Finally, the formulated curcumin has an increased oral bioavailability in animal models.

4.3.2 Astrakurkurol: Astrakurkurol, a triterpenoid extracted from fresh basidiocarps of the edible mushroom Astraeus hygrometricus was found to have anti-proliferative properties [50]. Astraeus hygrometricus has various health benefits such as anticancer, antidiabetic, and antioxidant properties [107-108]. Nandi and colleagues [50] demonstrated that astrakurkurol can act as a cytotoxic drug. It was found to induce apoptosis in hepatocarcinoma cell line (Hep3B) and arrest cell cycle at the $G_{0} / G_{1}$ phase. Following the establishment of the structural stability of astrakurkurol using single crystal Xray diffraction study and density functional theory calculations, the compound triggered the activation of caspase-8 and death receptor Fas protein mediated apoptotic events, inhibiting Akt and NF-KB pathway. Terpenoids generally account for a large numberof bioactive compounds implicated in the prevention and therapy of various diseases [109].

4.3.3 Chalcones: Functional chalcones are well implicated in natural anti-cancer therapy. In our data, Ji et al [51] reported that $2^{\prime}, 4^{\prime}$-Dihydroxy-6'-methoxy-3', $5^{\prime}$ dimethylchalcone (DMC), isolated from the buds of Cleistocalyx operculatus inhibit growth in HCC multi-drug resistant cell line BEL-7042/5-FU by triggering apoptosis via induction of cell cycle arrest at G1 achieved by the downregulation of CDK4 and cyclin D as indicated by flow cytometry analysis. DMC persuaded the up-regulation of Bad and Bax and decreased the expression of antiapoptotic Bcl-2 and Bcl-xL. DMC further increased levels of $\mathrm{p} 53$ and inhibited NF-KB nuclear-localization by suppressing PI3K/AKT signaling axis.

Wang et al [53] reported a similar chalcone; Licochalcone A (3-a, adimethylallyl-4,4'-dihydroxy-6methoxychalcone), LCA, a characteristic chalcone of licorice, a root of Glycyrrhiza inflata. LCA was purified using high-speed counter-current chromatography (HSCCC) technique followed by HPLC then tested with HepG2. Real-time PCR and flow cytometry revealed that the anti-cancer action of LCA involves an increase in mRNA expression of DR3, DR5, caspases-3, 8 and 9, Fas, $\mathrm{Bad}, \mathrm{Bax}$, and $\mathrm{BCl}-2$. Furthermore, LCA exhibits its antiproliferative effect against HepG2 cells by terminating the cell cycle at G2/M transition, thus suppressing genes involved in cell cycle progression.

4.3.4 Quercetin: Quercetin is a flavonoid compound present in many plants; its biological activities are related to the presence of five hydroxyl groups on its ring structure [110]. In this review, Ji et al [52] reported that quercetin inhibited the growth of human HCC cells in a dose-dependent manner while ensuring minimal cytotoxicity in normal liver cells. Analysis of autophagyrelated biomarkers using western blot and microscopy techniques dictates that quercetin induces autophagy by increasing both autophagosomes and autolysosomes in those cells, inhibiting AKT/mTOR pathway and activating the MAPK pathway. In vivo analysis using mice models further demonstrate the anti-tumor property of quercetin, which is associated with autophagy simulation and apoptosis induction as well.

4.3.5 Chlorogenic acid: In the report by Qi et al [57], chlorogenic acid, an active compound found in Athyrium multidentatum arrests cell cycle in HepG2 cells; it induces apoptosis through intrinsic and extrinsic pathways, modulating NFKB, MAPK/ERK, and PI3K/Akt pathways [57]. Chlorogenic acid (3-caffeoylquinic acid) is a polyphenol and the ester of caffeic and quinic acid, which is an important functional food in hepatocarcinoma cancer treatment and prevention [111]. 
4.3.6 Others: In this systematic review, we also established from our data various plant extracts that show effective anti-proliferative potential against hepatocarcinoma cancer cells through diverse mechanisms. Ginger polysaccharide (GP) induced apoptosis in HepG2 cells by arresting cell cycle at the GOG1 phase [54]. Analysis showed that GP consists of five monosaccharides including L-rhamnose, D-arabinose, Dmannose, D-glucose, and D-galactose in a molar ratio of 3.64: 5.37: 3.04: 61.03: 26.91 respectively. Also, real-time fluorescence quantitative PCR uncovered that GP increases the mRNA expression of Bax, Fas, p53, and caspase-3 with decreased expression of Bcl-2. Liu et al [56] reported that sesamol, extracted from sesame seed, suppressed colony formation, induced apoptosis in HepG2 cells by arresting cell cycle at $S$ phase and caused loss of mitochondrial membrane potential. Prunella vulgaris polysaccharide-zinc complex (P1-Zn), a modified polysaccharide extract from Prunella vulgaris inhibits proliferation by activation of caspase- 3 and -9 thereby inducing apoptosis [58]. In addition, biologically active extracts of Antrodia cinnamomea (EAC) sensitize HepG2 cells to sorafenib, thus causing cell death by targeting MAP kinases, modulating cyclin proteins expression, and inhibiting cancer cell invasion. Some of the bioactive compounds in the extract as determined by HPLC include Methyl antcinate B, Dehydroeburicoic acid, 15 $\alpha$-acetyl dehydrosulphurenic acid, Zhankuic acid $C$ and Antcin A, $C$, and $\mathrm{K}$ [55]. Lastly, extracts from Chinese Yam (Dioscorea opposite thunb.) containing compounds such as gallic acid, chlorogenic acid, vanillic acid, and epicatechin also showed antitumor properties against hepatocarcinoma tumor $(\mathrm{H} 22)$ model in rats [59]. Table 6 below shows the overall mechanisms of functional food components in hepatocarcinoma.

4.4 Overall Mechanism: The chemoprevention and anticancer mechanism of Functional Food components (FFc) has been expatiated in this review. In the graphical summary, one of the anti-cancer mechanisms of FFc is the inhibition of NF-k $\beta$ signaling. FFc impairs the translocation of NF-k $\beta$ into the nucleus for transcription induction. Therefore, cancer cells whose survival mechanism depends on NF-k $\beta$ will be challenged by the effect of FFc. Also, the ability of FFc to inhibit NF-k $\beta$ signaling means that the transcriptional target of NF-k $\beta$ (TRAF and an inhibitor of caspase-8) will not be induced. This together with the capacity of functional foods to sustain the expression of caspase-8 will therefore increase apoptosis in cancer cells.

TNF- $\alpha$ signaling also promotes apoptosis. TNF- $\alpha$ signaling enables the proteolytic activity of caspase- 8 and the activation of upstream kinases that triggers the availability and activation of JNK, whose resultant effect is pivotal to the active role of p53. FFc upregulates the expression of $\mathrm{p} 53$ which is a transcriptional factor and a guardian of the genome, and p21 which is the product of p53 transcriptional activities. The activity of p53 can be altered by PI3-Akt signaling, a way by which this is prevented is a close regulation of this shunt. FFc inhibits the PI3-Akt signaling, therefore availing the p53mediated activities including ROS generation and synthesis of p21. p21 inhibit CDK/Cyclin heterodimers, which leads to cell cycle arrest.

Events that cause mitochondrial membrane permeability to cytochrome c are critical to caspase- 9 mediated induction of apoptosis. One of such intramitochondrial events is the dimerization of Bax and Bak. Another anti-cancer mechanism of FFc is to upregulate the Bax and caspase-9 to induce apoptosis.

\section{CONCLUSION}

In conclusion, functional foods contain active components and or compounds that can serve as antitumor agents as a result of their great antioxidant 
property [112]. Studies in this review identified diverse plant products with their various screens of bioactive components, which offer prophylactic and curative measures in human cancer cells - cervical, breast, and liver cancers. These properties are related to the presence of antioxidant behavior of these components which enhanced their anti-cancer mechanism [113]. Moreover, the established anti-cancer mechanisms include apoptosis, reinforcement of anchorage dependent growth, inhibition of metastases, tumor microenvironment modification, cell cycle arrest, ROS generation, control of gene expression, and regulation of signaling shunts. Therefore, functional foods exhibit possible tremendous therapeutic capacity against cervical, breast, and liver cancers.

Abbreviations: FFc: Functional Food components, FUFOSE: Functional Food Science in Europe, FOSHU: Foods for Specified Health Use, IARC: International Agency for Research on Cancer, HBV: Hepatitis B virus, HCC: Hepatocellular carcinoma, DT-13: Dwarf-lillyturf Tuber monomer-13, LBP: Lycium barbarum polysaccharide, LBGP-I-3: Arabinogalactan, MBVP: Mungbean Vicilin Protein, DMC: 2',4'-Dihydroxy-6'-

\section{REFERENCES}

1. Al-Nabulsi AA, Obiedat B, Ali R, Osaili TM, Bawadi $H$, Abushelaibi A, et al.: Knowledge of probiotics and factors affecting their consumption by Jordanian college students. Int J Probiotics and Prebiotics 2014, 9(3):77-86.

2. Butnariu M, Caunii A: Design management of functional foods for quality-of-life improvement. Ann Agric Environ Med 2013, 20(4):736-741.

3. Cha MH, Lee J, Song MJ. Dieticians' intentions to recommend functional foods: The mediating role of consumption frequency of functional foods. Nutr Res Pract. 2010, 4(1):75-81. DOI: $10.4162 / \mathrm{nrp} .2010 .4 .1 .75$

4. Schnettler B, Miranda H, Lobos G, Sepulveda J, Orellana L, Mora $M$, et al.: Willingness to purchase functional foods according to their benefits. British Food Journal 2015, 177(5):1453-1473.

http://dx.doi.org/10.1108/BFJ-07-2014-0273 methoxy-3',5'-dimethylchalcone, QCT: Quercetin, LCA: Licochalcone A, MPD: Methyl Protodioscin, DI: 15,16Dihydrtanshinone, EAF: Ethylacetate Fraction, CLA: c9,t11-conjugated linoleic acid, CLO: Syzygium aromaticum, DMC: 2',4'-Dihydroxy-6'-methoxy-3', 5' $^{\prime}$ dimethylchalcone, ROS: Reactive Oxygen Species, Gallic acid, CGC; cyanidin-3-O-glucoside chloride, GP: Ginger polysaccharide, P1-Zn: Prunella vulgaris polysaccharidezinc complex, PGG: Penta-1,2,3,4,6-O-galloyl- $\beta$-Dglucose, Non-muscle myosin II-A (NMII-A).

Authors Contribution: Conceptualization; J.O.T.; writing - initial draft preparation, J.O.T., K.S.A., O.T.O., and T.I.A.; writing - review and editing, J.O.T., K.S.A., O.T.O., TKAT., T.I.A., MVB., YAJ., SQ., EMA., A.R., and GEB; supervision, JOT., T.I.A., and O.T.O.

Disclosure of Conflict: The authors report no conflicts of interest. The authors alone are responsible for the content and writing of this article.

Funding: This work was funded by CAPES (Coordination for the Improvement of Higher Education Personnel) in Brazil.

5. Lovik M: Impact of a New European regulations on functional food market - an overview. Clin Trans Allergy 2011, 1(1):55. https://doi.org/10.1186/2045-7022-1-S1-S55

6. Food and Agriculture Organization of the United Nations (FAO): authors Report on Functional Foods, Food Quality and Standards Service (AGNS) 2007.

7. European Commission report on functional foods: European Union 2010.

http://www.eurosfaire.prd.fr/7pc/documents/1276590504_func tional_foods_en_publi_ce.pdf. DOI:10.2791/21607

8. Kolarzyk E, Pach D: Different aspects of food consumed by contemporary people. Przegl Lek69 2012, 69(8):492-497.

9. Bilgiç S, Yüksel A: University students' perception and attitudes towards functional foods in Istanbul. Proceedings of the 2012 International Conference on Industrial Engineering and Operations Management Istanbul, Turkey. 2012. 
http://iieom.org/ieom2012/pdfs/279.pdf(20.12.2015).

10. Stein AJ, Rodriguez-Cerezo E: Functional food in the European Union. JRC Scientific and Technological Reports, Luxemburg, European Communities. 2008. DOI:10.2791/21607

11. Arai S: Studies on functional foods in Japan-State of the art. Biosci. Biotech. Biochem 1996, 60:9-15. DOI: https://doi.org/10.1007/978-4-431-67017-9 9

12. Meyer A: The 1998 top 100 R\&D survey. Food Processing 1998, 58(8):32-40.

13. Waltham MS: Roadmaps to Market: Commercializing Functional Foods and Nutraceuticals, Decision Resources, Inc. 1998, 5.

14. Teibo J, Bello S, Olagunju A, Olorunfemi F, Ajao O and Fabunmi O: Functional foods and bioactive compounds: Roles in the prevention, treatment and management of neurodegenerative diseases. GSC Biological and Pharmaceutical Sciences, 2020, 11(2), 297-313. DOI: $10.30574 /$ gscbps.2020.11.2.0143

15. Tonstad S, Butler T, Yan R, Fraser GE: Type of Vegetarian Diet, Body Weight and Prevalence of Type 2 Diabetes. Diabet Care 2009, 32:791-796. DOI: 10.2337/dc08-1886

16. Erdman JW Jr, Balentine D, Arab L, Beecher G, Dwyer JT, Folts J, et al.: Flavonoid and heart health: Proceedings of the ILSI North America Flavonoids Workshop, May 31-June 1, 2005, Washington, DC. J Nutr. 2007, 81(1):718S-737S https://doi.org/10.1093/jn/137.3.718S

17. Rodriguez EB, Flavier ME, Amaya DBR, Farfan JA: Phytochemicals and functional foods. Current situation and prospect for developing countries. Seguranca Alimentar e Nutricional, Campinas 2006, 13(1):1-22.

DOI: https://doi.org/10.20396/san.v13i1.1841

18. National Cancer Institute 2017.

http://www.cancer.gov/publications/dictionaries/cancerterms/ idiopathic.

19. Global Initiative for Cancer Registry Development. Lyon: International Agency for Research on Cancer; 2020 (https://gicr.iarc.fr/about-the-gicr/the-value-of-cancer-data/, accessed August 2021).

20. GLOBOCAN 2018; https://www.uicc.org/new-global-cancerdata-globocan-2018

21. Jemal A, Siegel R, Ward E, Hao Y, Xu J, Thun MJ: Cancer statistics, 2009. CA Cancer J. Clin. 2009, 59:225-249.

https://doi.org/10.3322/caac.20006

22. Bissonauth V, Shatenstein B, Ghadirian P: Nutrition and breast cancer among sporadic cases and gene mutation carriers: An overview. Cancer Detect Prev 2008, 32:52-64.

DOI: $\underline{10.1016 / j . c d p .2008 .01 .005}$
23. Perou CM, Sørlie T, Eisen MB, van de Rijn M, Jeffrey SS, Rees CA, et al.: Molecular portraits of human breast tumours. Nature 2000, 406:747-752. DOI: $10.1038 / 35021093$

24. Rachel EE, David JD, Craig DS Darrell LE: Breast Cancer in the Personal Genomics Era. Curr Genomics 2010, 11:146-16. DOI:10.2174/138920210791110951

25. Lynette D, Isaac A, Folakemi O, Timothy R, Makeda J. Williams, et al.: African Organisation for Research and Training in Cancer (AORTIC) Cancer Plan for the African Continent 2013-2017. 2013.

26. Gong G, Liu Q, Deng Y, Dang T, Dai W, Liu T, et al.: Arabinogalactanderived from Lycium barbarum fruit inhibits $c$ ancer cell growthvia cell cycle arrest and apoptosis. Int J Biol Macromol. 2020, 15(149):639-650. DOI: 10.1016/j.ijbiomac.2020.01.251

27. Ma YL, Zhang YS, Zhang F, Zhang YY, Thakur K, Zhang JG, et al.: Methyl protodioscin from Polygonatum sibiricum inhibits cervical cancer through cell cycle arrest and apoptosis induction. Food Chem Toxicol. 2019, 132:110655. DOI: $10.1016 /$ j.fct.2019.110655

28. Alvarez-Sala A, Attanzio A, Tesoriere L, Garcia-Llatas G, Barberá $\mathrm{R}$, Cilla A: Apoptotic effect of a phytosterol-ingredient and its main phytosterol ( $\beta$-sitosterol) in human cancer cell lines. Int J Food Sci Nutr. 2019, 70(3):323-334.

DOI: $10.1080 / 09637486.2018 .1511689$

29. Luo J, Meng X, Su J, Ma H, Wang W, Fang L, et al.: Biotin-Modified Polylactic- co-Glycolic Acid Nanoparticles with Improved Antiproliferative Activity of 15,16-Dihydrotanshinone I in Human Cervical Cancer Cells. J Agric Food Chem. 2018, 5:66(35):9219-9230. https://doi.org/10.1021/acs.jafc.8b02698

30. Bourgou S, Bettaieb Rebey I, Mkadmini K, Isoda H, Ksouri R, Ksouri WM: LC-ESI-TOF-MS and GC-MS profiling of Artemisia herba-alba and evaluation of its bioactive properties. Food Res Int. 2017, 99(1):702-712. DOI: 10.1016/j.foodres.2017.06.009

31. Zhang $Q$, Zhang F, Thakur K, Wang J, Wang H, Hu F, et al.: Molecular mechanism of anti-cancerous potential of Morin extracted from mulberry in Hela cells. Food Chem Toxicol. 2018, 112:466-475. DOI: 10.1016/j.fct.2017.07.002

32. Lin $\mathrm{TH}$, Hsu WH, Tsai PH, Huang $\mathrm{YT}$, Lin $\mathrm{CW}$, Chen $\mathrm{KC}$, et al.: Dietary flavonoids, luteolin and quercetin, inhibit invasion of cervical cancer by reduction of UBE2S through epithelialmesenchymal transition signaling. Food \& Function 2017, 8(4):1558-1568. https://doi.org/10.1039/c6fo00551a

33. Esposito T, Sansone F, Franceschelli S, Del Gaudio P, Picerno P, Aquino R, et al: Hazelnut (Corylus avellana L.) Shells Extract: 
Phenolic Composition, Antioxidant Effect and Cytotoxic Activity on Human Cancer Cell Lines. Int J Mol Sci. 2017, 18(2):392. DOI:10.3390/ijms18020392

34. Kim MJ, Kim SS: Antioxidant and antiproliferative activities in immature and mature wheat kernels. Food Chem. 2016, 196:638-645. DOI: 10.1016/j.foodchem.2015.09.095

35. Stojković DS, Barros L, Calhelha RC, Glamočlija J, Ćirić A, van Griensven, $\sqcup$, et al: A detailed comparative study between chemical and bioactive properties of Ganoderma lucidum from different origins. Int J Food Sci Nut. 2013, 65(1):42-47. DOI: $10.3109 / 09637486.2013 .832173$

36. Chen MH, Choi SH, Kozukue N, Kim HJ, Friedman M: GrowthInhibitory Effects of Pigmented Rice Bran Extracts and Three Red Bran Fractions against Human Cancer Cells: Relationships with Composition and Antioxidative Activities. J Agric Food Chem. 2012, 60(36):9151-9161. DOI: 10.1021/jf3025453

37. Zhu CP, Zhang SH: Lycium barbarum polysaccharide inhibits the proliferation of Hela cells by inducing apoptosis. J Sci Food Agric. 2013, 93(1)149-156. DOI: 10.1002/jsfa.5743

38. Choudhury D, Das A, Bhattacharya A, Chakrabarti G: Aqueous extract of ginger shows antiproliferative activity through disruption of microtubule network of cancer cells. Food and Chem Toxicol. 2010, 48(10):2872-2880.

DOI: $10.1016 / \mathrm{j} . f c t .2010 .07 .020$

39. Kim H, Moon JY, Mosaddik A, Cho SK: Induction of apoptosis in human cervical carcinoma HeLa cells by polymethoxylated flavone-rich Citrus grandis Osbeck (Dangyuja) leaf extract. Food Chem Toxicol. 2010, 48(89):2435-2442. DOI: $10.1016 / \mathrm{j} . f c t .2010 .06 .006$

40. Gao Y, Khan GJ, Wei X, Zhai KF, Sun L, Yuan S: DT13 inhibits breast cancer cell migration via nonmuscle myosin II-A regulation in tumor microenvironment synchronized adaptations. Clin Trans Oncol. 2020, 22(9), 1591-1602. DOI: 10.1007/s12094-020-02303-z

41. Zeng Y, Liu P, Yang X, Li H, Li H, Guo Y, et al: The dietary c9,t11conjugated linoleic acid enriched from butter reduces breastca ncer progression in vivo. J Food Biochem. 2020, 6:e13163. DOI: $\underline{10.1111 / \mathrm{jfbc} .13163}$

42. Kim GY, Suh J, Jang JH, Kim DH, Park OJ, Park SK, et al:Genistein Inhibits Proliferation of BRCA1 Mutated Breast Can cer Cells: The GPR30 Akt Axis as a Potential Target. J Cancer Prev. 2019, 24(4):197-207. DOI: 10.15430/JCP.2019.24.4.197

43. Gupta N, Srivastava N, Bhagyawant SS. Vicilin: A major storage protein of mungbean exhibits antioxidative pot ential, antiproliferative effects and ACE inhibitory activity. PLoS One 2018, 13(2):e0191265. DOI: 10.1371/journal.pone.0191265

44. Uifălean A, Schneider S, Gierok P, lonescu C, luga CA, Lalk M: The Impact of Soy Isoflavones on MCF-7 and MDA-MB-

231 Breast Cancer Cells Using a Global Metabolomic Approach. Int J Mol Sci. 2016, 17(9):E1443.DOI: 10.3390/ijms17091443

45. Kubatka P, Uramova S, Kello M, Kajo K, Kruzliak P, Mojzis J, et al:Antineoplastic effects of clove buds (Syzygium aromaticum ) in the model of breast carcinoma. J Cell Mol Med. 2017, 21(11):2837-2851.. DOI: 10.1111/jcmm.13197

46. Guimarães DAB, De Castro DDSB, de Oliveira FL, Nogueira EM, da Silva MAM, TeodoroAJ:Pitaya Extracts Induce Growth Inhibition and Proapoptotic Effects on Human CellLines of Breast Cancer via Downregulation of Estrogen Receptor Gen eExpression. Oxid Med Cell Longev. 2017, 7865073. DOI: $10.1155 / 2017 / 7865073$

47. Clement YN, Mahase V, Jagroop A, Kissoon K, Maharaj $A$, Mathura $P$, et al: Herbal remedies and functional foods used by cancer patients attendingspecialty oncology clinics in Trinida d. BMC Altern medicine 2016, 16(1):399.

DOI: $10.1186 / \mathrm{s} 12906-016-1380-\mathrm{x}$

48. Tang EL, Rajarajeswaran J, Fung S, Kanthimathi MS: Petroselinum crispum has antioxidant properties, protects agai nst DNA damageand inhibits proliferation and migration of canc er cells. J Sci Food Agric 2015, 95(13):2763-71.

DOI: $\underline{10.1002 / j s f a .7078}$

49. Liao SC, Hsu WH, Huang ZY, Chuang KL, Lin KT, Tseng CL, et al: Bioactivity Evaluation of a Novel Formulated Curcumin. Nutrients 2019, 11(12):2982. DOI: $10.3390 /$ nu11122982

50. Nandi S, Chandra S, Sikder R, Bhattacharya S, Ahir M, Biswal D, et al.: Characterization and inception of a triterpenoid astrakurkurol, as a cytotoxic molecule on human hepatocellular carcinoma cells, Hep3B. J Agric Food Chem. 2019, 11:2982. DOI: https://doi.org/10.1021/acs.jafc.9b01203

51. Ji X, Wei X, Qian J, Mo X, Kai G, An F, et al.: 2',4'-Dihydroxy-6'methoxy-3',5'-dimethylchalcone induced apoptosis and G1 cell cycle arrest through PI3K/AKT pathway in BEL-7402/5-FU cells. Food Chem Toxicol. 2019, 131:110533. DOI: 10.1016/j.fct.2019.05.041

52. Ji Y, Li L, Ma YX, Li WT, Li L, Zhu HZ, et al.: Quercetin inhibits growth of hepatocellular carcinoma by apoptosis induction in part via autophagy stimulation in mice. J Nutr Biochem. 2019, 69:108-119. DOI: 10.1016/j.jnutbio.2019.03.018 
53. Wang J, Zhang YS, Thakur K, Hussain SS, Zhang JG, Xiao GR., et al.: Licochalcone A from licorice root, an inhibitor of human hepatoma cell growth via induction of cell apoptosis and cell cycle arrest. Food Chem Toxicol 2018, 120:407-417.

DOI: $10.1016 / \mathrm{j} . f c t .2018 .07 .044$

54. Wang $\mathrm{Y}$, Wang $\mathrm{S}$, Song $\mathrm{R}$, Cai J, Xu J, Tang $\mathrm{X}$, et al.: Ginger polysaccharides induced cell cycle arrest and apoptosis in human hepatocellular carcinoma HepG2 cells. Int J Bio Macromol. 2018, 123:81-90. DOI: 10.1016/j.ijbiomac.2018.10.169

55. Wu WD, Chen PS, Omar HA, Arafa EA, Pan HW, Jeng J, et al.: Antrodia cinnamomea boosts the anti-tumor activity of sorafenib in xenograft models of human hepatocellular carcinoma. Sci Rep. 2018, 8(1):12914. DOI: 10.1038/s41598-018$\underline{31209-8}$

56. Liu Z, Ren B, Wang Y, Zou C, Qiao Q, Diao Z et al.: Sesamol Induces Human Hepatocellular Carcinoma Cells Apoptosis by Impairing Mitochondrial Function and Suppressing Autophagy. Sci Rep 2017, 7:45728. DOI: $\underline{10.1038 / \text { srep45728 }}$

57. Qi G, Liu Z, Fan R, Yin Z, Mi Y, Ren B, et al: Athyrium multidentatum (Doll.) Ching extract induce apoptosis via mitochondrial dysfunction and oxidative stress in HepG2 cells. Sci Rep 2017, 7(1):2275. DOI: $10.1038 / \mathrm{s} 41598-017-02573-8$

58. Li C, Huang Q, Xiao J, Fu X, You L, Liu RH: Preparation of Prunella vulgaris polysaccharide-zinc complex and its antiproliferative activity in HepG2 cells. Int J Bio Macromol. 2016, 91:671-679. DOI: 10.1016/j.ijbiomac.2016.06.012

59. Liu Y, Li H, Fan Y, Man S, Liu Z, Gao W, et al.: Antioxidant and Antitumor Activities of the Extracts from Chinese Yam (Dioscorea opposite Thunb.) Flesh and Peel and the Effective Compounds. J Food Sci 2016, 81(6):H1553-H1564.

DOI: $10.1111 / 1750-3841.13322$

60. Chen M, Meng H, Zhao Y, Chen F, Yu S: Antioxidant and in vitro anticancer activities of phenolics isolated from sugar beet molasses. BMC Complement Altern Med. 2015, 15:313.

DOI: $10.1186 / \mathrm{s} 12906-015-0847-5$

61. Dong $Y$, Yin S, Jiang C, Luo X, Guo X, Zhao C, et al: Involvement of autophagy induction in penta-1,2,3,4,6-O-galloyl- $\beta$-D-glucoseinduced senescence-like growth arrest in human cancer cells. Autophagy 2014, 10(2):296-310.

DOI: $10.4161 /$ auto. 27210

62. Olaoba OT, Akinyemi OA. Prophylactic Effect of Ascorbic Acid on Certain Biochemical and Histopathological Indices In Rats Treated With Repeated Dose of Cyclophosphamide. Trop J Nat Prod Res. 2018, 2(4):185-190. DOI: $\underline{10.26538 / \text { tjnpr/v2i4.6 }}$
63. American Cancer Society: Cancer Facts and Figures. Atlanta, Ga: American Cancer Society, 2020.

64. Ale MT, Maruyama H, Tamauchi H, Mikkelsen JD, Meyer AS: Fucoidan from Sargassum sp. and Fucus vesiculosus reduces cell viability of lung carcinoma and melanoma cells in vitro and activates natural killer cells in mice in vivo. Int J Biol Macromol. 2011, 49:331-336.DOI: 10.1016/j.ijbiomac.2011.05.009

65. Zaccheaus OA, Olamide TO, Kehinde SA, Amos OA, Temitope IA: The Role of BFl-1 in Cancer Unravels Inhibition Mechanism. Cancer Bio. 2019, 9(3):92-100. DOI: 10.7537/marscbj090319.11

66. Tahsin T, Wansi JD, Al-Groshi A, Evans A, Nahar L, Martin C, et al: Cytotoxic properties of the stem bark of Citrus reticulata Blanco (Rutaceae). Phytother Res. 2017, 31:1215-1219. DOI: $10.1002 /$ ptr. 5842

67. Yaacob NS, Yankuzo HM, Devaraj S, Wong JKM, Lai CS: Antitumor action, clinical biochemistry profile and phytochemical constituents of a pharmacologically active fraction of S. crispus in NMU induced rat mammary tumour model. PLoS One 2015, 10:e0126426. DOI: 10.1371/journal.pone.0126426

68. Tsai SL, Suk FM, Wang Cl, Liu DZ, Hou WC, Lin PJ, et al.: Antitumor potential of 15,16- dihydrotanshinone I against breast adenocarcinoma through inducing G1 arrest and apoptosis. Biochem Pharmacol. 2007,74:1575-1586. DOI: $\underline{10.15430 / J C P .2018 .23 .2 .63}$

69. Cai Y, Zhang W, Chen Z, Shi Z, He C, Chen M: Recent insights into the biological activities and drug delivery systems of tanshinones. Int. J. Nanomed. 2016, 11:121-130. DOI: $\underline{10.2147 / \text { IJN.S84035 }}$

70. Chang LC, Wu CL, Liu CW, Chuo WH, Li PC, Tsai TR: Preparation, characterization and cytotoxicity evaluation of tanshinone IIA nanoemulsions. J. Biomed. Nanotechnol. 2011, 7: 558-567.

DOI: $10.1166 / j b n .2011 .1315$

71. Li Q, Wang $Y$, Feng N, Fan Z, Sun J, Nan Y: Novel polymeric nanoparticles containing tanshinone IIA for the treatment of hepatoma. J Drug Target 2008, 16:725-732. DOI: $\underline{10.1080 / 10611860802374303}$

72. Wang L, Lai Y, Li C, Jiang X: Study on the intestinal absorption profiles of tanshinone IIA and its inclusion complex with cyclodextrin in rats. PDA J Pharm Sci Technol. 2009, 63: 390-400.

73. Wang X, Lin J, Li G, Qiu M, Wang Y: Development of salvianolic acid B-tanshinone IIA-glycyrrhetinic acid compound liposomes: Tissue distribution in vivo of mice and evaluation of the liver targeting. Nanomedicine 2016, 12:497-497.

DOI: $\underline{10.1016 / j . i j p h a r m .2013 .12 .040 ~}$ 
74. Kang J, Zhang P, Gao Z, Zhang J, Yan Z, Wang H, et al: Naphthohydroquinones, naphthoquinones, anthraquinones, and a naphthohydroquinone dimer isolated from the aerial parts of Morinda parvifolia and their cytotoxic effects through upregulation of p53. Phytochemistry 2016, 130:144-151. DOI: 10.1016/j.phytochem.2016.04.001

75. Ghantous A, Gali-Muhtasib H, Vuorela H, Saliba NA, Darwiche N: What made sesquiterpene lactones reach cancer clinical trials?. Drug Discov Today 2010, 15: 668-678. DOI: 10.1016/j.drudis.2010.06.002

76. Brown J, Oprey J, Harrison PR: Enhanced sensitivity of human oral tumours to the flavonol, morin, during cancer progression: involvement of the Akt and stress kinase pathways. Carcinogenesis 2003, 24:171-177. https://doi.org/10.1093/carcin/24.2.171

77. Chung SS, Oliva B, Dwabe S, Vadgama JV: Combination treatment with flavonoid morin and telomerase inhibitor MST312 reduces cancer stem cell traits by targeting STAT3 and telomerase. Int J Oncol. 2016, 49:487-498

DOI: $\underline{10.3892 / \text { ijo.2016.3546 }}$

78. Hyun HB, Lee WS, Go SI, Nagappan A, Park C, Han MH, et al.: The flavonoid morin from Moraceae induces apoptosis by modulation of $\mathrm{Bcl}-2$ family members and Fas receptor in HCT 116 cells. Int J Oncol. 2015, 46:2670.

DOI: $\underline{10.3892 / \text { ijo.2015.2967 }}$

79. Jin H, Lee WS, Eun SY, Jung JH, Park HS, Kim G, et al.: Morin, a flavonoid from Moraceae, suppresses growth and invasion of the highly metastatic breast cancer cell line MDA-MB231 partly through suppression of the Akt pathway. Int J Oncol. 2014, 45: 1629-1637. DOI: 10.3892/ijo.2014.2535

80. Karthik KV, Vennila S, Nalini N: Modifying effects of morin on the development of aberrant crypt foci and bacterial enzymes in experimental colon cancer. Food Chem Toxicol. 2009, 47:309. DOI: $10.1016 / j . f c t .2008 .11 .017$

81. Okarter, N. Liu C, Sorrells, M.E, Liu RH: Phytochemical content and antioxidant activity of six diverse varieties of whole wheat. Food Chemistry 2010, 119;249-257. DOI: $10.1016 /$ j.foodchem.2009.06.021

82. Zhang Y, Liu J, Kuo J, Yu J, Yu B: DT-13 suppresses MDA-MB-435 cell adhesion and invasion by inhibiting MMP-2/9 via the p38 MAPK pathway. Mol Med Rep. 2012, 6(5):1121. https://doi.org/10.3892/mmr.2012.1047

83. Khan GJ, Rizwan M, Abbas M, Naveed M, Boyang $Y$, Naeem MA, et al.: Pharmacological effects and potential therapeutic targets of DT-13. Biomed Pharmacother. 2018, 97:255-263.
DOI: $10.1016 /$ j.biopha.2017.10.101

84. Babbin BA, Koch S, Bachar M, Conti MA, Parkos CA, Adelstein RS, et al.: Non-muscle myosin IIA diferentiallyintestinal epithelial cell restitution and matrix invasion. Am J Patholss. 2009, 174(2):436. DOI: $10.2353 /$ ajpath.2009.080171

85. Dahiya, DK, Puniya AK: Conjugated linoleic acid enrichedskim milk prepared with Lactobacillus fermentum DDHI27 endorsed antiobesity in mice. Future Microbiol 2018, 13: 1007-1020. DOI: $\underline{10.2217 / \mathrm{fmb}-2017-0280}$

86. Koronowicz AA, Banks P: Antitumor properties of CLA enriched food products. Nutr Cancer 2018, 70:529-545.

DOI: $10.2217 / \mathrm{fmb}-2017-0280$

87. Wang X, Wu J: Modulating effect of fatty acids and sterols on skin aging. J Fun Food 2019, 57(6):135-140. DOI: $10.1016 /$ j.jff.2019.04.011

88. Manzo N, Pizzolongo F, Montefusco I, Aponte M, Blaiotta G, Romano R: The effects of probiotics and prebiotics on the fatty acid profile and conjugated linoleic acid content of fermented cow milk. Int J Food Sci Nutr. 2015, 66(3):254-259. DOI: $\underline{10.3109 / 09637486.2014 .992005}$

89. Verrucka S, Dantasb A, Prudencio ES: Functionality of the components from goat's milk, recent advances for functional dairy products development and its implications on human health. J Fun Food 2019, 52:243-257. https://doi.org/10.1016/j.jff.2018.11.017

90. El Roz A, Bard JM, Huvelin JM, Nazih H: The anti-proliferative and pro apoptotic effects of the trans9, trans11 conjugated linoleic acid isomer on MCF-7 breast cancer cells are associated with LXR activation. Prostaglandins Leukot Essent Fatty Acids 2013,

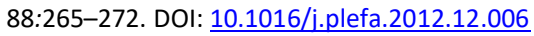

91. Kulczyński BA, Gramza-Michałowska A. Goji berry (Lycium barbarum): Composition and health effects-a review. Pol J Food Nutri Sci. 2016, 66(2):67-75. DOI: https://doi.org/10.1515/pifns-2015-0040

92. Ganai AA, Farooqi $\mathrm{H}$ : Bioactivity of genistein: a review of in vitro and in vivo studies. Biomed Pharmacother. 2015, 76:30-8.

DOI: 10.1016/j.biopha.2015.10.026

93. Spagnuolo C, Russo GL, Orhan IE, Habtemariam S, Daglia M, Sureda A: Genistein and cancer: current status, challenges, and future directions. Adv Nutr. 2015, 6:408-419.

DOI: $10.3945 / a n .114 .008052$

94. Lamartiniere CA, Cotroneo MS, Fritz WA, Wang J, Mentor-Marcel R, Elgavish A: Genistein chemoprevention: timing and mechanisms of action in murine mammary and prostate. J Nutr. 2002, 132(3):552S-558S.. DOI: 10.1093/jn/132.3.552S 
95. Frey RS, Li J, Singletary KW: Effects of genistein on cell proliferation and cell cycle arrest in nonneoplastic human mammary epithelial cells: involvement of Cdc2, p21(waf/cip1), p27(kip1), and Cdc25C expression. Biochem Pharmacol. 2001, 61:979-989.DOI: 10.1016/s0006-2952(01)00572-x

96. Cappelletti V, Fioravanti L, Miodini P, Di Fronzo G: Genistein blocks breast cancer cells in the $\mathrm{G}(2) \mathrm{M}$ phase of the cell cycle. J Cell Biochem. 2000, 79:594-600.610.

97. Wu WL, Wu GJ, Liang DS, Yang F: The physiological function and research progress of angiotensin-I-converting enzyme inhibitory peptides. Mod Food Sci Tech. 2006, 22:251-254.

98. Kuiper GG, Lemmen JG, Carlsson B, Corton JC, Safe SH, van der Saag PT, et al.: Interaction of estrogenic chemicals and phytoestrogens with estrogen receptor B. Endocrinology 1998, 139:4252-4263.

DOI: $10.1210 /$ endo.139.10.6216

99. Toledo E, Salas-Salvado J, Donat-VargasC, Buil-Cosiales P, Estruch R, Ros E, et al.: Mediterranean Diet and Invasive Breast Cancer Risk among Women at High Cardiovascular Risk in the PREDIMED Trial: a Randomized Clinical Trial. JAMA Intern Med. 2015, 175(11):1752-1760

DOI: 10.1001/jamainternmed.2015.4838

100. Castello A, Pollan M, Buijsse B, Ruiz A, Casas AM, Baena-Canada JM, et al.: Spanish Mediterranean diet and other dietary patterns and breast cancer risk: case-control EpiGEICAM study. $\mathrm{Br} \mathrm{J}$ Cancer 2014, 111(7):1454-1462. DOI: 10.1038/bjc.2014.434

101. Fung TT, Chiuve SE, Willett WC, Hankinson SE, Hu FB, Holmes MD: Intake of specific fruits and vegetables in relation to risk of estrogen receptor-negative breast cancer among postmenopausal women. Breast Cancer Res Treat. 2013, 138(3):925-930. DOI: 10.1007/s10549-013-2484-3

102. Kumar PS, Febriyanti RM, Sofyan FF, Luftimas DE, Abdulah R: Anticancer potential of Syzygium aromaticumL. in MCF-7 human breast cancer cell lines. Pharmacognosy Res. 2014, 6(4):350354. DOI: $\underline{10.4103 / 0974-8490.138291}$

103. Vora SR, Patil RB and Pillai MM: Protective effects of Petroselinumcrispum (Mill) Nyman ex AW Hill leaf extract on Dgalactose-induced oxidative stress in mouse brain. Indian J Exp Biol 2009, 47:338-342.
104. Fejes S, Kery A, Blazovics A, Lugasi A, Lemberkovics E, Petri G: Investigation of the in vitro antioxidant effect of Petroselinumcrispum (Mill.) Nym. Ex AW Hill. Acta Pharm Hung 1998, 68(3):150-156

105. Haryuna TS, Munir D, Maria A, Bashiruddin J: The antioxidant effect of curcumin on cochlear fibroblasts in rat models of diabetes mellitus. Iran J Otorhinolaryngol. 2017, 29:197-202.

106. Jurenka JS: Anti-inflammatory properties of curcumin, a major constituent of Curcuma longa: A review of preclinical and clinical research. Altern Med Rev. 2009, 14:141-153.

107. Biswas G, Chatterjee S, Sarkar S, Acharya K: Evaluation of Antioxidant and Nitric Oxide Synthase Activation Properties of Astraeus hygrometricus (Pers.) Morg. Int J Biomed Pharma Sci. 2010, 4:21-26.

108. Lai TK, Biswas G, Chatterjee S, Dutta A, Pal C, Banerji J, et al.: Leishmanicidal and anticandidal activity of constituents of Indian edible mushroom Astraeus hygrometricus. Chem Biodiversity 2012, 9(8):1517-1524

DOI: $10.1002 / c b d v .201100272$

109. Thoppil RJ, Bishayee A: Terpenoids as potential chemopreventive and therapeutic agents in liver cancer. World J. Hepatol. 2011, 3(9):228-249. DOI: 10.4254/wjhv3.i9.228

110. Khan F, Niaz K, Maqbool F, Ismail Hasssan F, Abdollahi M, Nagulapalli Venkata KC, et al.: Molecular Targets Underlying the Anticancer Effects of Quercetin: An Update. Nutrients 2016, 8(9):529. DOI: 10.3390/nu8090529

111. Lukitasari M, Nugroho DA, Widodo N. Chlorogenic Acid: The Conceivable Chemosensitizer Leading to Cancer Growth Suppression. J Evid Based Integr Med. 2018, 23:2515690X18789628. DOI: $\underline{10.1177 / 2515690 \times 18789628}$

112. Teibo JO, Akinfe OA, Olagunju AS, Olorunfemi FG, Teibo TKA, Olaoba OT, et al.: Chemo-preventive roles of Medicinal foods against Environmental carcinogens-induced Cancers. W Can Res J 2021; 8: e2102. DOI: 10.32113/wcri 202192102

113. Teibo JO, Ayinde KS, Olaoba OT, Adelusi TI. Chemopreventive roles and their mechanism of functional foods and bioactive components in cervical, breast, and liver cancers: A systematic review. Paper presented at $13^{\text {th }}$ Breast Gyanecological and Immuno-oncology Interntaional Conference 2021. DOI: $\underline{10.13140 / R G .2 .2 .28075 .98089}$ 